\title{
Traditional Chinese Technology of Crucible Lead Smelting: A Comprehensive Study Based on Historical Records and Archaeological Findings
}

\section{ZHOU Wenli 周文丽,1 LIU Siran 刘思然,2 LIU Haifeng 刘海峰, ${ }^{3}$ CHEN Jianli 陈建立, ${ }^{4}$ Thilo REHREN 任天洛 ${ }^{5}$}

(1. Institute for the History of Natural Sciences, Chinese Academy of Sciences, Beijing 100190, China; 2. Institute for Cultural Heritage and History of Science $\mathcal{E}$ Technology, University of Science and Technology Beijing, Beijing 100083, China; 3. Institute for History of Science E Technology, Nanjing University of Information Science \& Technology, Nanjing 210044, China; 4. School of Archaeology and Museology, Peking University, Beijing 100081, China; 5. STARC, The Cyprus Institute, Nicosia 27456, Cyprus)

\begin{abstract}
Crucible lead smelting, a traditional technology unique to China, refers to the production of lead by reducing lead sulfide with iron metal in crucibles. In recent years, a number of crucible lead production sites of the Liao-Jin-Yuan periods (tenth-fourteenth centuries $\mathrm{CE}$ ) have been found in northern China, providing opportunities for the study of the technology. This paper provides a comprehensive overview of this technology based on the historical and archaeological evidence, with particular emphasis on the crucibles used. Firstly, it reviews the historical records on crucible lead smelting, and introduces, in detail, the technology used in Gansu during the Qing period (1644-1911) as well as indigenous methods used in the twentieth century; secondly, it summarizes the discoveries of crucible lead smelting sites in recent years, and reconstructs the
\end{abstract}

Received: January 22, 2021. Revised: May 27, 2021.

This paper is sponsored by "Preliminary Research on Ancient Chinese Crucible Smelting Technology" (Approval No.: 51404242) and "Research on Ancient Iron Reducing Silver and Lead Smelting Technology" (Approval No.: 51704023) of the Youth Science Foundation of the National Natural Science Foundation of China, and the Major Breakthrough project "Research on Ancient Chinese Crucible Smelting Technology" (Approval No.: Y621011003) of the Institute for the History of Natural Sciences, Chinese Academy of Sciences.

The paper was translated into English by Gao Wenrui 高文睿 and copyedited by Elizabeth Hughes.

1 Research interest: History of metallurgy. Email: zhouwenli@ihns.ac.cn

2 Research interest: History of metallurgy. Email: siran.liu@ustb.edu.cn

3 Research interest: History of technology. Email: ustb_liuhaifeng@126.com

4 Research interest: History of metallurgy. Email: jianli_chen@pku.edu.cn

5 Research interest: History of metallurgy, glass, and ceramics. Email: th.rehren@cyi.ac.cy 
manufacturing of crucibles and the iron reduction method by analysis of the crucible and slag; finally, it expounds the technical characteristics of crucible lead smelting, and explores the origin and development of the technology.

Keywords: crucible lead smelting, crucible, iron reduction, coal

摘 要：坩埚炼铅是中国特有的一种传统炼铅技术, 即在坩埚中用金属铁从硫化铅中还 原出铅。近年来在北方地区发现一批辽金元时期（公元一千纪后期至二千纪前期）的坩 埚炼铅遗址, 为研究该技术提供了契机。本文将基于文献和考古两方面证据, 以使用的 坩埚为重点, 对该技术进行综合研究。首先, 回顾有关坩埚炼铅的文献资料, 详细介绍 清代甘肃坩埚炼铅的情况, 以及 20 世纪土法坩埚炼铅的工艺流程; 其次, 总结近年来 坩埚炼铅遗址的发现情况, 通过坩埚和炉渣的分析来复原坩埚的制作工艺、铁还原法等 技术; 最后, 阐述坩埚炼铅的技术特征, 并探讨技术起源与发展等问题。

关键词：坩埚炼铅，坩埚，铁还原法，煤炭

\section{Introduction}

As metal production lays the material foundation for human civilization and social 1 development, metallurgy plays an important part in the history of civilization and science and technology. To a certain extent, ancient Chinese civilization was created by copper and iron (Hua 1999; Han and Ke 2007), resulting in numerous basic studies on the origin, development, and spread of copper and iron production in the field of history of metallurgy and archaeometallurgy. Other metals, such as lead, tin, zinc, gold, and silver, also play a significant role in ancient Chinese civilization, the research on whose metallurgical technology, however, is insufficient by contrast.

Lead $(\mathrm{Pb})$, a gray white metal with a molecular weight of 207.2, is known to have a high density $\left(11.34 \mathrm{~g} / \mathrm{cm}^{3}\right)$ and a low melting point $\left(327^{\circ} \mathrm{C}\right)$. Lead is easily smeltable and presumably the first metal smelted by man (Glumac and Todd 1987; Hansen et al. 2019). During the Xia, Shang, and Zhou periods (circa 2070-256 BCE), lead was mainly used in the production of bronze ware as well as lead ware and solder. Since the Qin (221-206 BCE) and Han periods (206 BCE-220 CE), lead was widely used to produce copper coins, bronzes, minium, gunpowder, and bullion. Lead smelting generally used cerussite (lead carbonate, $\mathrm{PbCO}_{3}$ ) and galena (lead sulfide, $\mathrm{PbS}$ ). Galena was the most widespread ore. It was directly burned in a hearth in an oxidizing atmosphere to produce lead oxide and lead sulfide, which then reacted to obtain metallic lead; or galena was first roasted in a hearth to generate lead oxide, which was then reduced in a furnace to produce lead metal. Silver, if contained in the obtained lead metal, could then be extracted by cupellation (Han and Ke 2007, 316-319).

Compared to research on the technology of copper and iron smelting, less has been done on that of lead in ancient China. The technology of lead smelting was brought to scholars' knowledge by Song Yingxing 宋应星, a scientist in the Ming dynasty (13681644), whose work The Exploitation of the Works of Nature (Tiangong kaiwu 天工开物, 
1637) contains the earliest detailed record of lead smelting ever found (Xia, Wang, and Li 1980, 277-281; Hua 1999, 452; He 2009, 620). This book describes three categories of lead: lead from argentiferous lead ore, copper-lead ore, and pure lead ore. Argentiferous lead ore was smelted in hearths, while copper-lead ore and pure lead ore in furnaces (Song [1637] 2008, 154). In addition, a crucible lead production technology was recorded in a memorial to the throne by the governor of Gansu Province in the Qing dynasty (Han and Ke 2007, 317-318).

An in-depth analysis of lead smelting technology in ancient China relies much on the inquiry into lead-silver smelting sites. Some furnace smelting sites dating from the Tang (618-907) and Song (960-1279) to the Qing periods have been found in provinces of Zhejiang (Zheng and Yan 2007; Xiang and Zheng 2008; Qi et al. 2012), Guangxi (Li and Zhou 2000), Jiangxi (Liu 2015, 317-323; Liu et al. 2015; Liu et al. 2016; Liu et al. 2018), and the Chongqing Municipality (Xie and Rehren 2009) in southern China and in Henan Province (Li 2007, 71-72) in northern China. In recent years, some crucible lead smelting sites have been found in northern China. Li Yanxiang first showed a picture of lead smelting crucible fragments from the Liao (907-1125)-Jin (1115-1234)-Yuan (12711368) periods at the Qiannangou site, Pingquan County, Hebei Province (Han and Ke 2007, 317). In 2009, when the Ding Kiln in Quyang County, Hebei Province was excavated, a crucible smelting site was found in Yanchuan, which was identified to be used for lead smelting according to preliminary analysis. Later, Chen Jianli and his coworkers investigated the Weishan site in Tongbai County, Henan Province, and the Gangguantun Kiln site in Liaoyang City, Liaoning Province, and found smelting remains similar to those from Yanchuan.

With the crucible lead smelting sites discovered one after another, a range of studies have been carried out by our research team led by Chen Jianli. Liu Siran systematically analyzed the smelting remains from Yanchuan, and suggested with a simulation experiment that an iron reduction method was used. He also discussed the use of coal as fuel in crucible lead smelting with a reflection on the early use of coal in metallurgy more generally (Liu 2015, 317-323; Liu et al. 2019). Liu Haifeng argued that Yanchuan site produced lead for the nearby Litongjian Mint in the Jin period (Liu and Chen 2019). Zhou Wenli reviewed the historical records on crucible lead smelting and reconstructed the technology based on preliminary analysis of smelting remains (Zhou et al. 2014). She also analyzed the remains from Weishan and Gangguantun and reconstructed the technology used at the two sites (Zhou, Liu, and Chen 2017; Guo 2018).

This paper intends to give a summary of the recent research progress in the Chinese crucible lead smelting technology. It reviews two sources of historical records of crucible lead smelting, introduces the discovery of fourteen smelting sites with a discussion of location choice, and reconstructs the ancient technology based on the analysis of smelting remains from five sites. On this basis, this paper sums up the four 
technical features of the technology and explores its origin and development, in the hope of gaining a better understanding of the technology.

\section{Historical records of crucible lead smelting technology}

\subsection{Crucible lead smelting in Gansu Province in the Qianlong period of the Qing dynasty}

At present, the only known historical record related to crucible lead smelting in ancient China is in a memorial by the Gansu governor, Wu Dashan, on the twenty-fifth day of the first lunar month of the twenty-second year of Qianlong's reign (March 14, 1757) (IQHRUC and TRSCPSHDARUC 1983, 382-383). According to the memorial, in 1746 Gansu Province was exploiting the lead mine in Heishichuan, Gaolan County, Lanzhou Prefecture (nowadays Gaolan County, Lanzhou City, Gansu Province), and the Ministry of Works agreed to sell the lead at 0.04 liang 两 of silver per jin 斤. 6 Later, the lead mine in Heishichuan collapsed, and the mining was forced to stop. In 1756, the Gaolan people requested to exploit the Xiqueling lead mine in Fuling Prefecture, Ningxia Province (nowadays Wuzhong City, Ningxia Province), and the governments of both provinces set the price of lead at 0.05 liang of silver per jin. The Ministry of Works ordered $\mathrm{Wu}$ Dashan to investigate the cause of the price increase. According to $\mathrm{Wu}^{\prime}$ 's report, the lead ore used in the trial smelting had to be transported from Xiqueling to Dalachi, Jingyuan County, Lanzhou Prefecture (nowadays Jingyuan County, Baiyin City, Gansu Province. See Figure 4) some 110 li 里 $^{7}$ away. The cost of raw materials, fuel, labor, and other things for smelting of each furnace was listed in detail (Table 1). It was calculated that for each jin of lead smelted, the cost was 0.042 liang of silver. Given the further cost of transporting it to Lanzhou 330 li away, Wu upheld the price of lead at 0.05 liang of silver per jin.

According to the cost list of trial production, a furnace at that time contained 100 crucibles, which were filled with 450 jin of lead ore and more than 190 jin of cast iron, and presumably 675 jin of coal were consumed as fuel. A total of 225 jin of pure lead was obtained, indicating a content of more than $50 \%$ lead in the ore. It can be calculated that one crucible, charged with $2.7 \mathrm{~kg}$ of lead ore and $1.1 \mathrm{~kg}$ of cast iron, can produce $1.3 \mathrm{~kg}$ of lead. This method employs metallic iron and lead ore in crucibles to obtain lead, which is typical of an iron reduction method. In the trial, two laborers were hired to crush and fill the ore and pull the bellow, and a lead-separating craftsman to smelt the lead. Other required materials included firewood, wheat straws, extinguishing

6 Liang and jin are traditional Chinese units of weight. In the Qing dynasty, 1 jin $=16$ liang $=$ $597 \mathrm{~g}$.

$7 \mathrm{Li}$ is a traditional Chinese unit of length. In the Qing dynasty, $1 l i=559.8 \mathrm{~m}$. 
water, coal for crude lead refining, and so on. The list also includes the cost of all the materials in the process (Table 1). Calculations show that cost was mostly spent on the ore $(53.5 \%)$ and metallic iron $(28.0 \%)$, followed by the freight of the ore $(8.4 \%)$, crucibles $(4.0 \%)$, and coal $(3.9 \%)$, the payment for the two laborers and the lead-separating craftsmen $(1.1 \%$ and $0.6 \%$, respectively), and lastly firewood, wheat straws, extinguishing water, coal for refining, and other functional materials $(0.5 \%$ in total). This record plays a significant part in understanding the ancient crucible lead smelting technology and its expense.

Table 1: The cost of lead ore trial production in Xiqueling during the Qianlong period

\begin{tabular}{cccc}
\hline Item & Amount & Cost (liang) & Proportion (\%) \\
\hline Ore & 450 jin & 5.06 & 53.5 \\
Freight of ore & $140 \mathrm{li}$ & 0.797 & 8.4 \\
Crucibles & 100 & 0.375 & 4.0 \\
Metallic iron & 192.7 jin & 2.65 & 28.0 \\
Coal & 650 jin & 0.371 & 3.9 \\
Firewood & 1 bundle & 0.0075 & 0.1 \\
Wheat straws & 1 bundle & 0.00625 & 0.1 \\
Extinguishing water & 6 dan & 0.0075 & 0.1 \\
Ore crushing/filling \& bellow pulling & 2 laborers & 0.1 & 1.1 \\
Lead separating & 1 craftsman & 0.06 & 0.6 \\
Coal for crude lead refining & 40 jin & 0.022 & 0.2 \\
Total & & 9.46 & 100 \\
Pure lead produced & 225 jin & & \\
\hline
\end{tabular}

\subsection{Indigenous methods of crucible lead smelting in the twentieth century}

The traditional crucible lead smelting technology was still used in many places in the twentieth century. In 1980, He Tangkun went to Shuikoushan, Changning County, Hunan Province, to investigate the traditional metallurgical technology and learned that crucible lead smelting had been applied in Shuikoushan before the 1950s (He 2009, 687-688). The Complete Collection of Traditional Chinese Arts and Crafts: Metalworking (Zhongguo chuantong gongyi quanji: Jinshu gongyi 中国传统工艺全集 - 金属工艺) cites a record of indigenous methods adopted in 1958, which contains a brief introduction of crucible lead smelting (Tan and Sun 2007, 50-51). There are also three brochures published in 1958 that record indigenous methods in Inner Mongolia, Beijing, and other places (Qinghai Ministry of Metallurgical Industry 1958; BMDIIMAR 1958; Beijing Public-Private Joint Smelting Plant 1958). In addition, a more detailed description of the lead smelting technology by crucible was found in the textbooks on lead metallurgy published in the 1960s and 1970s, but such records in textbooks became very brief in the 1990s, and do not appear whatsoever in the twenty-first century (DNMSNIT 1960, 254- 
258; DNMSNIT 1976, 296-299; CGMBZSP 1973; Chen 1992, 83; Peng 2004). However, in 1996, Li Xingzheng mentioned that this method was still widely used in the 1990s by individuals and township enterprises in the south of Hunan Province and the north of Guangdong Province (Li 1996). With the government ban on indigenous methods in recent years, this traditional lead production technology may no longer exist.

According to these records, when smelting lead in crucibles, a rectangular furnace was filled with dozens to hundreds of crucibles with lead ore, iron, and other raw materials in them, fueled by coal or coke, to obtain lead by reducing the lead ore with iron. Operations varied slightly from place to place. Relevant data are shown in Table 2. Specific steps of the smelting process, including furnace construction, crucible making, charge mixing, and smelting, are demonstrated as follows.

Table 2: Data of traditional crucible lead smelting in different places in the twentieth century

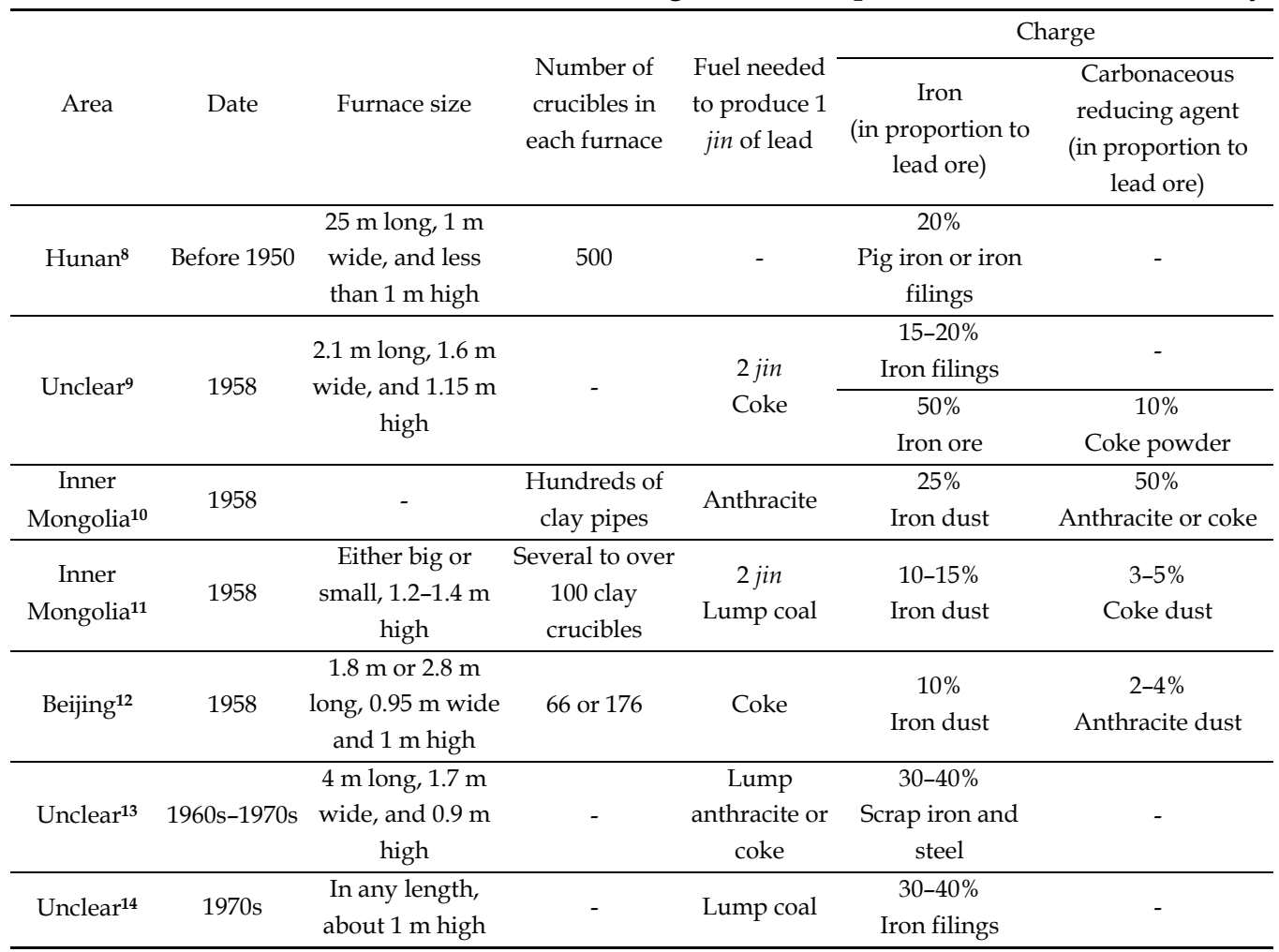

8 He (2009, 687-688).

9 Qinghai Ministry of Metallurgical Industry (1958).

10 BMDIIMAR (1958).

11 BMDIIMAR (1958).

12 Beijing Public-Private Smelting Joint Plant (1958).

13 DNMSNIT (1976, 296-299).

14 CGMBZSP (1973). 


\subsubsection{Furnace construction}

The furnace is rectangular, with three walls on two long sides and a short side, and a removable wall built on another short side (Figure 1). The volume of the furnace depends on the output of lead (or the number of crucibles). The furnace is usually about $1 \mathrm{~m}$ in height and 1-2 $\mathrm{m}$ in width to facilitate operation. The length varies from $1 \mathrm{~m}$ to several meters, while the furnace in Shuikoushan is $25 \mathrm{~m}$ long. The lower part of the furnace bottom is slightly wider than the upper to shape a trapezoid cross section, which saves fuel by ensuring the concentration of heat during firing. Adobe, broken bricks, or stones are used to make the three walls, which costs less but provides poor fire resistance. The walls can be also made of durable refractory bricks, whose interior is coated with a layer of coal dust or fireclay mixed with coke powder.

Adopting natural ventilation, the furnace is also called "the self-blast furnace," whose ventilating channel at the bottom has a significant influence on the smelting. The interior of the furnace is paved with a $5-10 \mathrm{~cm}$ thick layer of clay to make the bottom higher than the external ground, so that the air can be sent into the furnace from bottom to top. Five to ten lines of bricks are laid on the clay layer parallel to the long side of the furnace stack, with a spacing of about $10 \mathrm{~cm}$; a 1-2 cm gap is left between the bricks in a line to facilitate the air circulation in the furnace (Figure 1). Furnace bars made of fireclay or crucible fragments are placed horizontally on top of the brick bars, which enlarges the bottom space in the furnace, facilitates the ventilation, and keeps the upper coal from falling down. The removable wall is built over the bricks before loading crucibles, and it is pulled down for unloading crucibles and cleaning the furnace.
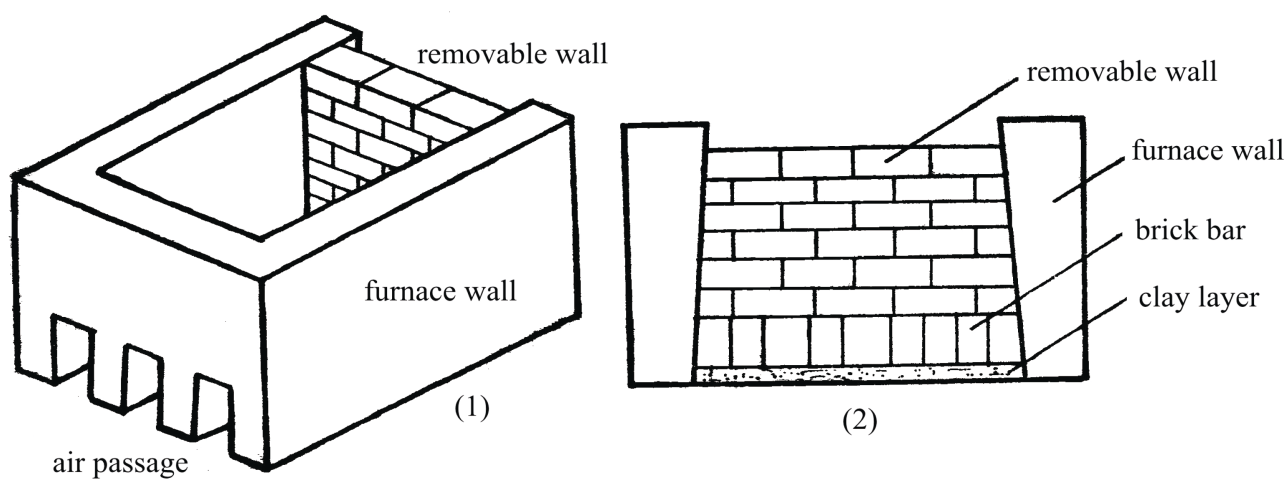

(2)

Figure 1: Graphic illustration of crucible lead smelting furnace (CGMBZSP 1973, 247).

\subsubsection{Crucible making}

The crucibles are mostly tubular, with a diameter of $10-16 \mathrm{~cm}$ and a height of $35-50 \mathrm{~cm}$; 
there are also cylindrical ones with a diameter of $25 \mathrm{~cm}$ and a height of only $32 \mathrm{~cm}$. The clay used for making crucibles should resist high temperatures. Usually, refractory clay (such as ganzitu 坩子土) mixed with a certain proportion of grog (such as cylinder sand) and coke or coal powder is used. The mixture should be made evenly, crushed with a roller, kneaded with feet or beaten with a wooden stick or iron rod, and finally covered with a wet cloth or sack for a few days. The crucible is usually made with a wooden mold. For the convenience of demolding, the wooden mold is dusted with dry powder or cylinder sand, and covered with a cloth cover, on which there are air holes and a string at the top to remove the cover (Figure 2). Finally, clay lumps are put on the cloth cover, pressed by hand, and then beaten with wooden planks. Before being fired, the crucibles need to be dried naturally beside the furnace until fully prepared.

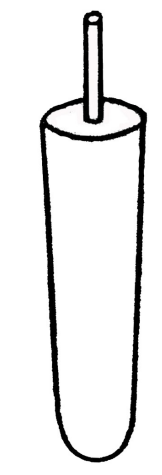

wooden mold

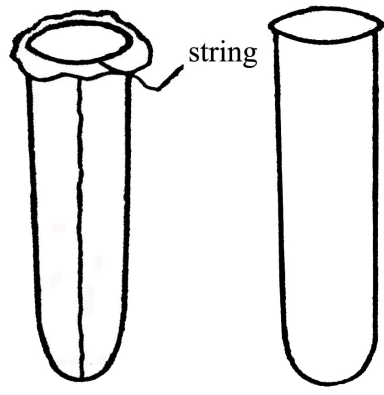

cloth cover crucible made

Figure 2: Graphic illustration of the making of crucibles (CGMBZSP 1973, 246).

\subsubsection{Charge}

The lead ore is galena, which is expected to contain more than $30 \%$ lead. Galena with a low grade is beneficiated by hand and water, and crushed to $0.5-1.5 \mathrm{~cm}$ in size. About $10-40 \%$ scrap iron (such as iron filings, iron powder, iron sheet, iron pieces, etc.) is added to the ore, the amount of which depends on the sulfur content in the ore; the added iron should not be rusted, which will otherwise affect the smelting. A certain amount of coal powder or coke powder, and sometimes a small amount of lime $\left(\mathrm{CaCO}_{3}\right)$ or soda $\left(\mathrm{Na}_{2} \mathrm{CO}_{3}\right)$ is added to the lead ore as flux and desulfurizer to improve the recovery of lead (Qinghai Ministry of Metallurgical Industry 1958). In cases where iron is not available, iron ore and other reducing agents (coke, charcoal) can be added into the crucible to produce iron, which then reduces the galena (Tan and Sun 2007; Qinghai Ministry of Metallurgical Industry 1958). ${ }^{15}$

15 Using iron ore in crucible lead smelting requires more carbonaceous reducing agent, which 


\subsubsection{Smelting process}

The removable wall is built before loading crucibles in the furnace for smelting. The furnace bars are covered with a layer of bottom coal, which is then paved with a layer of easily combustible materials (such as straw, sawdust, firewood, and charcoal). Coal of various sizes - extra-large, large, mid-size, and small - is loaded in layers with a total thickness of $40-80 \mathrm{~cm}$ (Figure 3). Crucibles are placed on top of the coal layer. When loading the crucibles, the bottoms of the crucibles must be held tightly to prevent cracking, and a $5-10 \mathrm{~cm}$ gap is left between the crucibles and the walls, which is later filled with crushed coal. The crucibles are covered with crucible fragments, tiles, or other ceramic pieces to keep the heat loss down. The firewood is ignited from the lower vent to ensure its fast combustion. In general, after smelting for three to eight hours, the charge melts and makes a sound like porridge being heated. When white smoke is no longer emitted from the crucible mouth, an iron rod or a drill rod is inserted into the crucible to test whether there is lead mixed in the upper "glaze" (also known as slag). A decrease in lead prills (recognizable by their glassy appearance) in the slag, indicates a complete reaction, meaning that the crucibles can be taken out of the furnace. Finally, the crucibles are broken and the slag in the upper layer and the ferrous sulfide in the middle layer are removed to obtain the metallic lead in the lowest layer, also referred to as "lead cake" or "lead egg." Crucible walls without slag can be crushed to substitute cylinder sand as grog to make new crucibles. The lead can be also separated from the slag after unloading the crucibles and before cooling, as lead is heavy while slag is light.

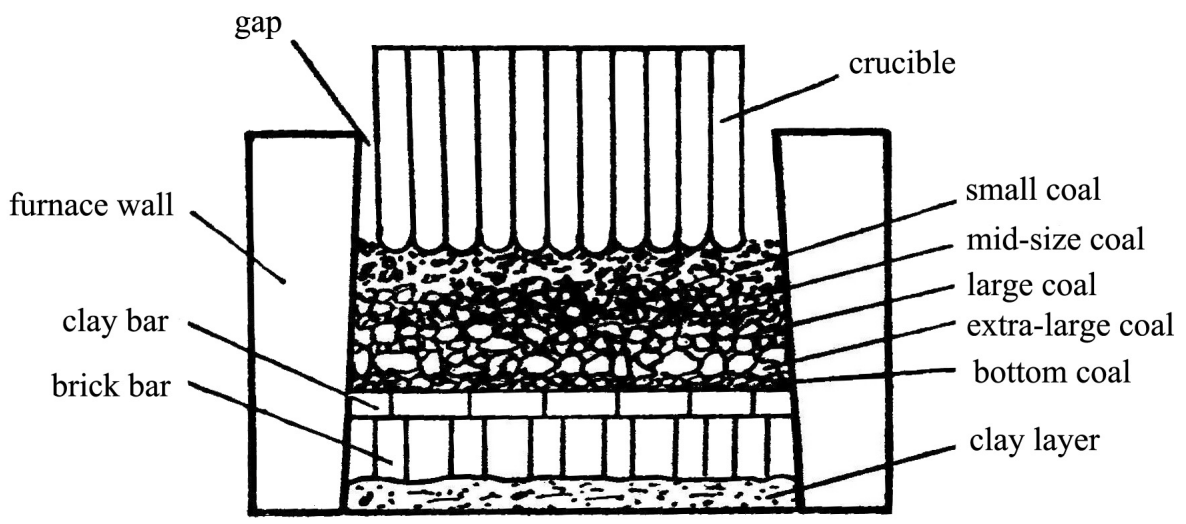

Figure 3: Graphic illustration of the loading of crucibles and coal in furnace (CGMBZSP 1973, 248).

occupies more space in the crucible, thus reducing the lead output of each crucible. This method has not been commonly used. 


\section{Discovery and research of crucible lead smelting sites}

\subsection{Discovery of crucible lead smelting sites}

The discovery and study of the Yanchuan, Weishan, and Gangguantun sites has contributed to a clearer understanding of the technology. According to previous archaeological reports, crucible lead smelting remains have been found in numerous regions, including Cijiawu Kiln in Fangshan District, Beijing (Zhao 1984), Hedongpo Kiln in Jingxing County (National Cultural Heritage Administration 2000), Panzhuang Kiln in Funing County (Wu et al. 2007, 41), Qiannangou in Pingquan County (Huang et al. 2008), Xitucheng in Kangbao County (DACHCHNU and CRPMIKC 2014, 63-77), and Tang County (Xie and Rehren 2009), all in Hebei Province, and Yicheng County in Shanxi Province (Cheng et al. 2012). Some archaeologists argue that the glassy substance in the crucible may be glaze frit, the material used for glaze making. But generally speaking, it is not necessary for porcelain glaze. In addition, communication with archaeologists has enlightened us that remains of crucible lead smelting were also found at Jininglu in Inner Mongolia, ${ }^{16}$ Duandian Kiln in Lushan County, Henan Province, ${ }^{17}$ Guciyao Kiln in Hunyuan County, and Liaocheng site, Ying County, both in Shanxi Province. ${ }^{18}$

So far, a total of fourteen crucible lead smelting sites have been discovered (Table 3 and Figure 4). In terms of distribution, most of them are in northern China, mainly in Hebei (six sites) and Shanxi (three sites), two in Henan, one in Inner Mongolia, one in Beijing, and one in Liaoning. Most of them date to the Liao, Song, Jin, or Yuan periods, while the sites in Yicheng may date back to the late Qing dynasty (Cheng et al. 2012); the date of the site in Tang County is still unknown.

These sites followed some rules on choice of locations (Table 3). Most significantly, half of the sites were found next to porcelain kiln sites, including Jingxing Kiln, Panzhuang Kiln, Ding Kiln, Guciyao Kiln, Duandian Kiln, Cijiawu Kiln, and Gangguantun Kiln. All were important porcelain kilns in the Liao-Jin-Yuan periods in northern China. Porcelain manufacturing used kaolinitic clay as raw material and coal as fuel, which were therefore both readily available also for crucible lead smelting. Metallic lead is an important raw material for producing low-fired lead glazed ceramic,

\footnotetext{
16 Professor Cui Jianfeng from Peking University informed us that he had seen lead smelting crucibles and copper melting crucibles in the findings from the Jininglu site of the Yuan dynasty in Inner Mongolia. In January 2016, Zhou Wenli went to the warehouse of the Horinger workstation where the Jininglu findings were stored, and found several copper melting crucibles, but no lead smelting crucibles were found.

17 Discovered by Professor Chen Jianli in October 2018.

18 Discovered by Professor Liu Yan, Institute of Archaeology of Shanxi Province, in 2008 and 2013.
} 
which, however, was not the main product in these kiln sites. Only a small amount of green and tricolor glazed pottery was produced in Ding Kiln, and some tricolor porcelain ware in Gangguantun Kiln (The Chinese Ceramic Society 1982, 234, 316). Therefore, it is inferred that lead in these kilns was rarely used as raw material to produce lead glaze, but for other purposes such as coin casting and silver smelting. According to Liu Haifeng's study, the Yanchuan site used to provide lead for coin casting at the Litongiian Mint in the Jin period, located in Quyang (Liu and Chen 2019). Therefore, it is assumed that crucible lead smelting in these kilns was mainly driven by the abundant kaolinitic clay and coal resources available. On the other hand, there are also sites located in cities. For example, in Ying County, crucibles were discovered in

Table 3: List of crucible lead smelting sites found so far

\begin{tabular}{|c|c|c|c|c|}
\hline Province & No. & Site & Approximate date & Location \\
\hline \multirow{6}{*}{$\begin{array}{l}\text { Hebei } \\
\text { 河北 }\end{array}$} & 1 & $\begin{array}{l}\text { Hedongpo Kiln, Jingxing County } \\
\text { 井陉县河东坡窑 }\end{array}$ & Jin period & Kiln \\
\hline & 2 & $\begin{array}{l}\text { Panzhuang Kiln, Funing County } \\
\text { 抚宁县潘庄窑 }\end{array}$ & Yuan period & Kiln \\
\hline & 3 & $\begin{array}{l}\text { Qiannangou, Pingquan County } \\
\text { 平泉县铅南沟 }\end{array}$ & Liao-Jin-Yuan periods & City \\
\hline & 4 & $\begin{array}{l}\text { Yanchuan, Ding Kiln, Quyang County } \\
\text { 曲阳县定窑燕川 }\end{array}$ & Jin-Yuan periods & Kiln \\
\hline & 5 & $\begin{array}{l}\text { Xitucheng, Kangbao County } \\
\text { 康保县西土城 }\end{array}$ & Jin period & City \\
\hline & 6 & $\begin{array}{l}\text { Tang County } \\
\text { 唐县 }\end{array}$ & $?$ & Unclear \\
\hline \multirow{3}{*}{$\begin{array}{l}\text { Shanxi } \\
\text { 山西 }\end{array}$} & 7 & $\begin{array}{l}\text { Guciyao Kiln, Hunyuan County } \\
\text { 浑源县古磁窑 }\end{array}$ & Liao-Jin periods & Kiln \\
\hline & 8 & $\begin{array}{l}\text { Liaocheng, Ying County } \\
\text { 应县辽城 }\end{array}$ & Liao-Jin periods & City \\
\hline & 9 & $\begin{array}{l}\text { Xiyan and Shijia, Yicheng County } \\
\text { 翼城县西阎、石家 }\end{array}$ & $?$ & Close to mine \\
\hline \multirow{2}{*}{$\begin{array}{l}\text { Henan } \\
\text { 河南 }\end{array}$} & 10 & $\begin{array}{l}\text { Weishan, Tongbai County } \\
\text { 桐柏县围山 }\end{array}$ & Song-Yuan periods? & Close to mine \\
\hline & 11 & $\begin{array}{l}\text { Duandian Kiln, Lushan County } \\
\text { 鲁山县段店窑 }\end{array}$ & Song-Jin periods? & Kiln \\
\hline $\begin{array}{l}\text { Beijing } \\
\text { 北京 }\end{array}$ & 12 & $\begin{array}{l}\text { Cijiawu Kiln, Fangshan District } \\
\text { 房山区磁家务窑 }\end{array}$ & Liao-Jin-Yuan periods & Kiln \\
\hline $\begin{array}{c}\text { Liaoning } \\
\text { 辽宁 }\end{array}$ & 13 & $\begin{array}{l}\text { Gangguantun Kiln, Liaoyang City } \\
\text { 辽阳市江官屯窑 }\end{array}$ & Liao-Jin-Yuan periods & Kiln \\
\hline $\begin{array}{c}\text { Inner Mongolia } \\
\text { 内蒙古 }\end{array}$ & 14 & $\begin{array}{l}\text { Jininglu, Ulanqab City } \\
\text { 乌兰察布市集宁路 }\end{array}$ & Yuan period & City \\
\hline
\end{tabular}




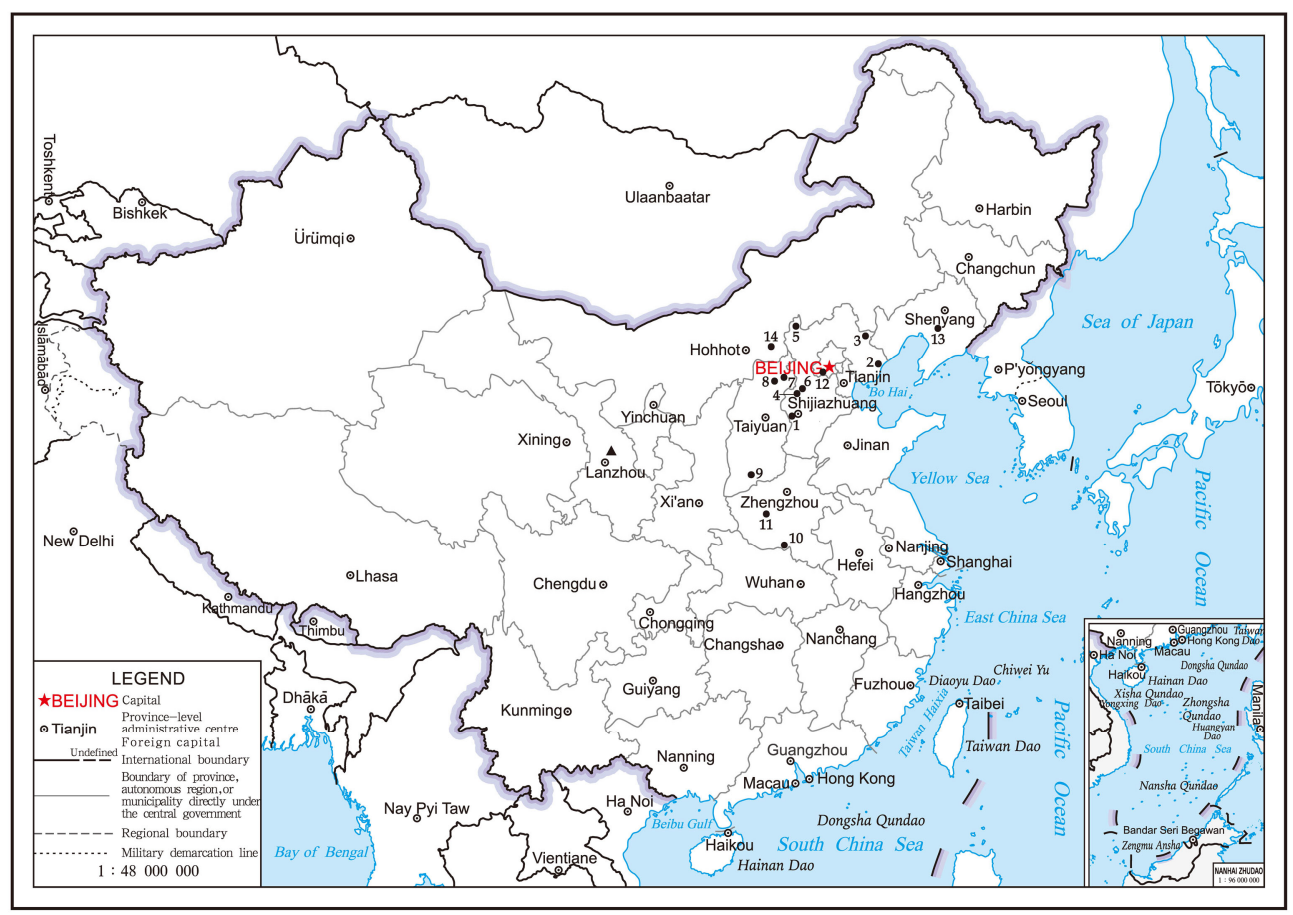

Figure 4: Map of crucible lead smelting sites in China. GS (2021) 3866

Black dots: The fourteen smelting sites as listed in Table 3.

The black triangle: Jingyuan County, Gansu Province.

the ash pit of a Liao-Jin city site; at the Jininglu site, crucibles were found in the ancient Jininglu City of the Yuan period. Crucibles for copper melting were also discovered at both sites, indicating the implementation of lead smelting and bronze casting at the same time. Factors contributing to the location of crucible lead smelting sites in cities include transport convenience, easy access to ore, iron, refractory clay, coal, and other resources, and the aggregation of talented craftsmen. In addition, a small number of sites were close to the mine, such as the Weishan site in Tongbai near the Poshan silver mine and the two sites in Yicheng near the lead-silver mine.

\subsection{Reconstruction of lead smelting technology based on crucible and slag analysis}

Since 2010, five sites have been investigated, including Yanchuan (QYS), Weishan (TW), Guciyao (HY), Liaocheng (YX), and Gangguantun (GGT), and crucible and slag samples have been collected for macroscopic observation, microscopic observation, and compositional analysis with the metallographic microscope and scanning electron microscope-energy dispersive spectrometer (SEM-EDS). The samples from Yanchuan were analyzed by Liu Siran (Liu et al. 2019). The experimental process of the samples 
from the other four sites was as follows: The slag-attached crucible walls were processed into metallographic samples with a standard preparation method, and then the microscopic morphology of the crucible and slag was observed and photographed with a Leica DM6000M metallographic microscope. SEM-EDS analysis was performed on the samples with a scanning electron microscope (Czech's Tescan Vega3) and energy dispersive spectrometry (Germany's Bruker Xflash 6160). The samples were carbon coated and the morphology and composition of the samples were observed under high vacuum at an accelerating voltage of $15-20 \mathrm{kV}$ and a working distance of $15 \mathrm{~mm}$. At 100x magnification, the composition was obtained based on three area-scans of each crucible and the slag, the averages of which were taken as the bulk composition; then the composition of individual sulfide and metal phases in the slag was analyzed. Based on the data obtained, the technology used in these sites was reconstructed.

\subsubsection{Crucible manufacturing}

All the crucibles are cylindrical in shape, most of them being the mid-part fragments filled with slag (Figure 5), with an external diameter of $7-9 \mathrm{~cm}$ and varying wall thickness. The thinner ones are $0.5-1 \mathrm{~cm}$, the thicker ones $1-2 \mathrm{~cm}$. The fragments are different in length, with the longer ones being about $20 \mathrm{~cm}$. They are mostly black, cyan gray, or beige, sometimes with slag flowing out on the exterior surface. In some sites, conical or hemispherical crucible bottoms were discovered. The bottoms were found to be thick and with no slag attached. The bottoms of crucibles at Panzhuang, Qiannangou,
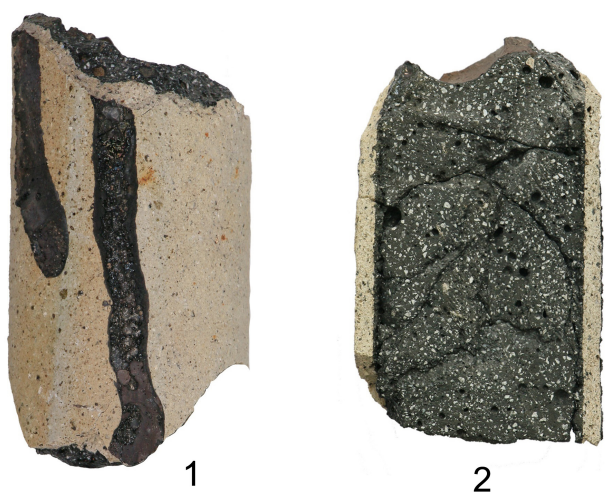

2

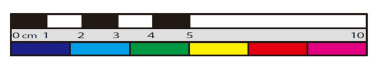

Figure 5: Mid-part of Weishan crucible TW01.

1. Exterior surface; 2. Cross section. 
Xitucheng, Guciyao, and Gangguantun sites were conical, while the ones at Weishan and Yanchuan sites were hemispherical (Figure 6). A $31.5 \mathrm{~cm}$ long crucible with an incomplete mouth and complete bottom (Figure 6.1) was excavated at Panzhuang Kiln, which is the most intact crucible ever found for lead smelting. Given no wheel marks on the surfaces of these crucibles, it is presumed that they may have been produced by molding.

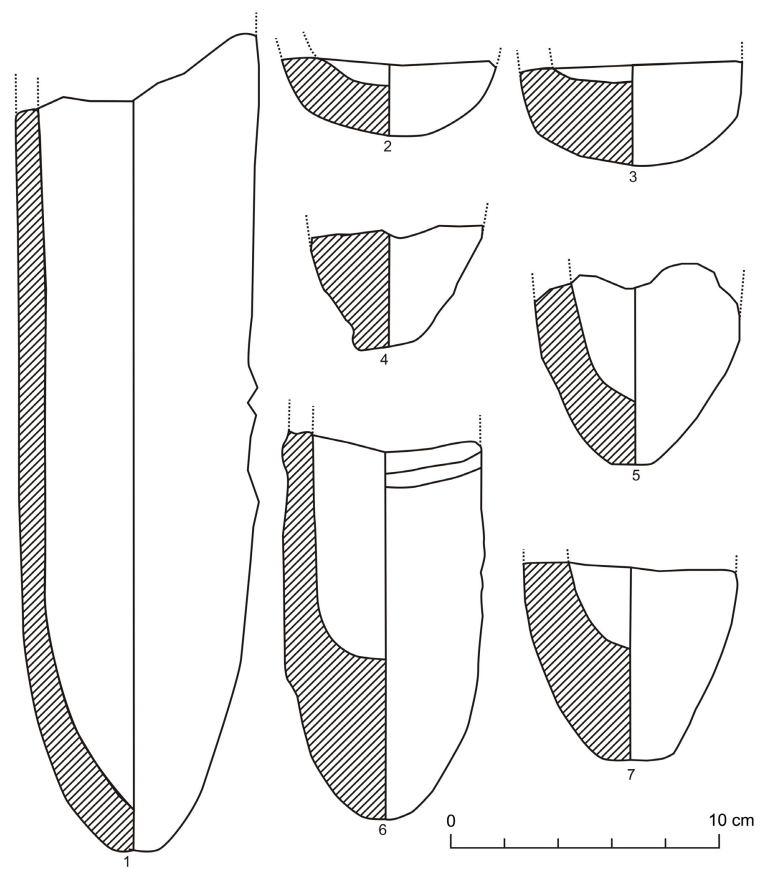

Figure 6: Crucible bottoms found at crucible lead smelting sites.

1. Panzhuang (Wu et al. 2007, 41); 2. Yanchuan; 3. Weishan (TW05); 4. Gangguantun; 5, Guciyao (HY03); 6. Xitucheng (DACHCHNU and CRPMIKC 2014, 73); 7. Qiannangou (Huang et al. 2008, 13).

The crucibles from the Yanchuan, Weishan, Guciyao, Liaocheng, and Gangguantun sites are all made of kaolinitic clay with a high content of $\mathrm{Al}_{2} \mathrm{O}_{3}$ and a small amount of $\mathrm{FeO}, \mathrm{K}_{2} \mathrm{O}, \mathrm{CaO}$, and other flux components (Table 4). According to the $\mathrm{FeO}-\mathrm{Al}_{2} \mathrm{O}_{3}-\mathrm{SiO}_{2}$ ternary phase diagram of the crucibles (Figure 7), the compositions of the crucibles from Yanchuan, Weishan, Guciyao, and Gangguantun are found gathered together, with similar content of $\mathrm{Al}_{2} \mathrm{O}_{3}$ (average 25-31\%), while only a few crucibles from Weishan and Gangguantun are found with special compositions, and Liaocheng crucibles have higher content of $\mathrm{Al}_{2} \mathrm{O}_{3}$ (average 37\%) and flux. Masses of high aluminacontent particles and a fraction of coal fragments were also found in the crucibles of these sites (Figure 8.1). The largest alumina-rich particles are 1-2 $\mathrm{mm}$ in size, with a similar composition to the matrix. At Yanchuan, Guciyao, Liaocheng, and Gangguantun, a small proportion of coal is contained in the crucibles, while only some 
crucibles at Weishan are found containing coal, some charcoal (Figure 8.2), though most crucibles contain neither. The matrices of these crucibles were highly sintered, but their inside is hardly fused with any slag, giving a clear boundary in between. The position of the crucible compositions in the ternary phase diagram (Figure 7) demonstrates that they consisted primarily of mullite $\left(\mathrm{Al}_{6} \mathrm{Si}_{2} \mathrm{O}_{13}\right)$. Mullite forms from the decomposition of kaolinitic clay at temperatures $\geq 1100^{\circ} \mathrm{C}$ (Martinón-Torres, Rehren, and Freestone 2006). As mullite is a chemically and thermally stable compound, its presence in the crucibles can greatly improve strength, thermal shock resistance, and thermal and chemical refractoriness, thus rendering a superior material for hightemperature operations (Martinón-Torres et al. 2008).

Table 4: Average bulk composition (wt $\%)$ of crucibles from five sites

\begin{tabular}{ccccccccccccc}
\hline Site & Sample number & $\mathrm{Na}_{2} \mathrm{O}$ & $\mathrm{MgO}$ & $\mathrm{Al}_{2} \mathrm{O}_{3}$ & $\mathrm{SiO}_{2}$ & $\mathrm{P}_{2} \mathrm{O}_{5}$ & $\mathrm{SO}_{3}$ & $\mathrm{~K}_{2} \mathrm{O}$ & $\mathrm{CaO}$ & $\mathrm{TiO}_{2}$ & $\mathrm{MnO}^{\mathrm{FeO}}$ \\
\hline Yanchuan (QYS) & 14 & - & 0.5 & 27.6 & 64.8 & - & 0.1 & 1.7 & 1.0 & 1.4 & - & 2.8 \\
Weishan (TW) & 12 & 0.3 & 0.8 & 25.2 & 63.0 & 0.2 & 0.7 & 2.1 & 1.5 & 1.4 & 0.3 & 4.4 \\
Guciyao (HY) & 3 & 0.2 & 0.7 & 30.9 & 61.7 & 0.1 & 0.4 & 1.3 & 0.9 & 1.2 & - & 2.5 \\
Liaocheng (YX) & 5 & 0.5 & 1.4 & 37.2 & 50.5 & 0.1 & 0.6 & 2.4 & 2.6 & 1.8 & 0.2 & 2.5 \\
Gangguantun (GGT) & 16 & 0.3 & 0.5 & 27.8 & 63.4 & 0.8 & 0.4 & 1.3 & 0.6 & 1.4 & - & 3.5 \\
\hline
\end{tabular}

It can be summarized that the crucible lead smelting used cylindrical crucibles with a conical or a hemispherical bottom, mostly made of kaolinitic refractory clay mixed with coal. The cylindrical crucible is typical of external heating, that is, the heating fuel is placed outside the crucible. Externally heated crucibles are usually deep and have a small opening to maintain the reducing atmosphere during the smelting process; the walls of such crucibles are thin, fire-resistant, and dense to ensure sound thermal conductivity, so that the heat can be transferred from the outside to the inside (Rehren 2003; Bayley and Rehren 2007). The discovered crucibles are a demonstration of what is typical of external heating crucibles in shape, material, and performance.

At present, no furnace has been found in these crucible lead smelting sites. In April 2013, a sintered furnace base for lead smelting was collected when investigating the Yanchuan site. The bottoms of nine crucibles and a large number of crucible sherds were still stuck on the coal cinder at the furnace base (Figure 9), indicating that these crucibles were lined in parallel rows, and close to each other, with very little space between them, in the furnace. It shows that the crucibles were heated with coal fuel at the bottom. The lead smelting furnace is probably similar to the rectangular one used in the indigenous method in the twentieth century. 


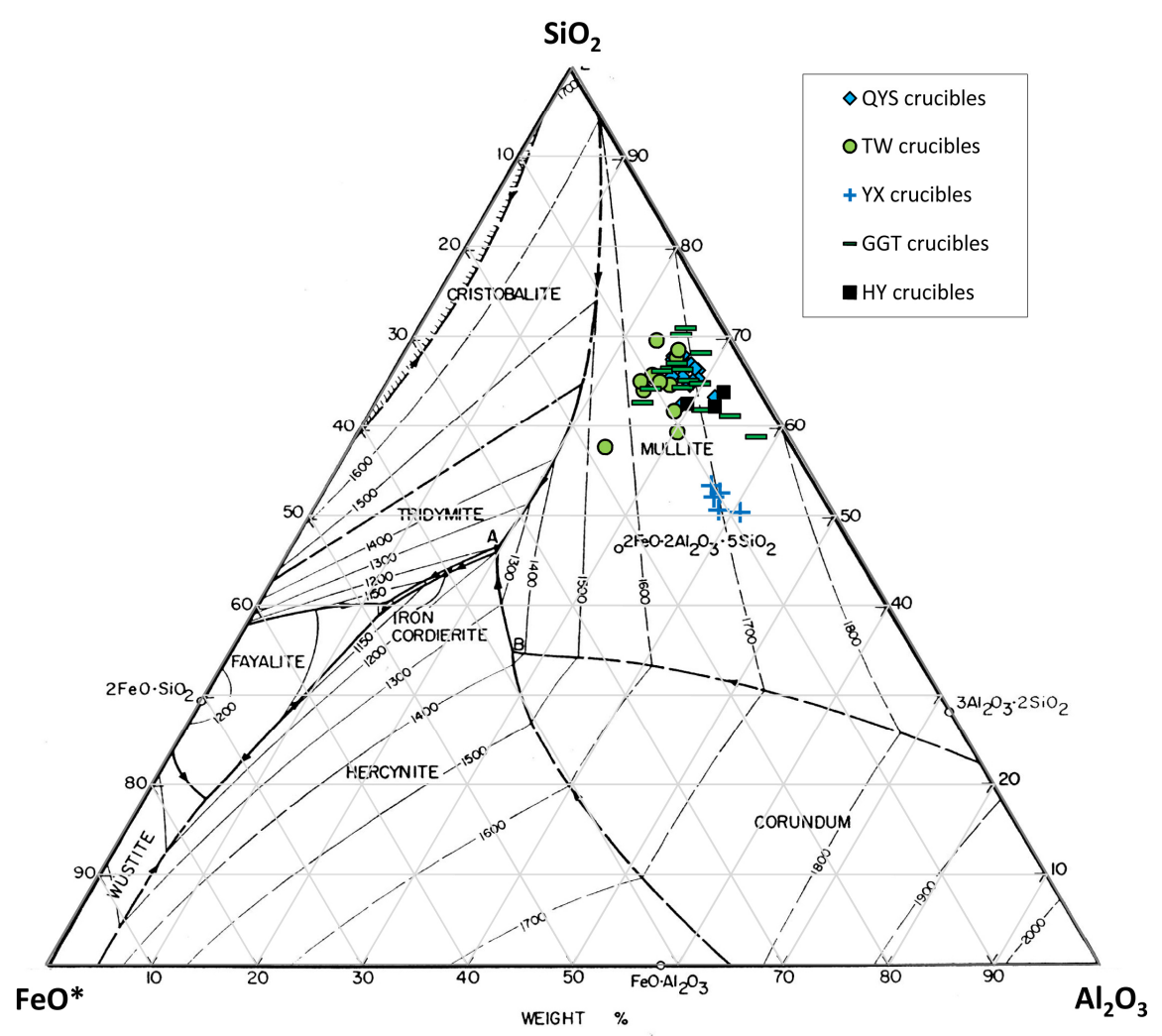

Figure 7: Projection of crucible compositions from five sites into the $\mathrm{SiO}_{2}-\mathrm{Al}_{2} \mathrm{O}_{3}$ (FeO+MeO) ternary phase diagram (after Muan 1957). ${ }^{19}$

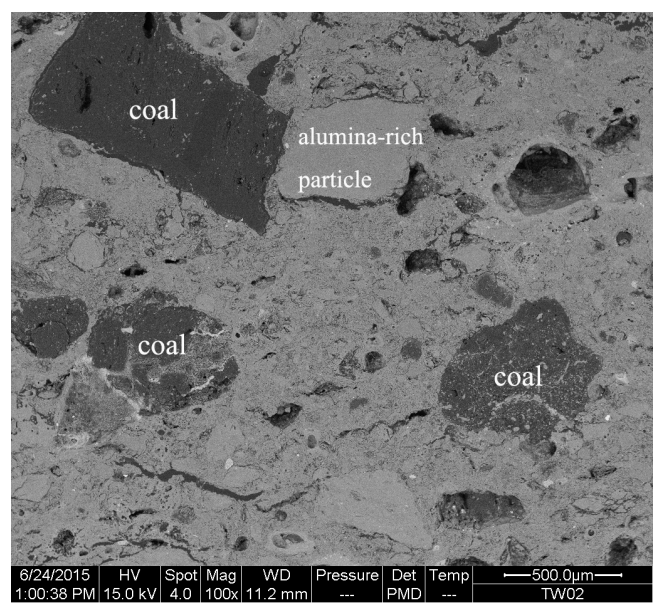

Figure 8.1: Coal fragments in Weishan crucible TW02.

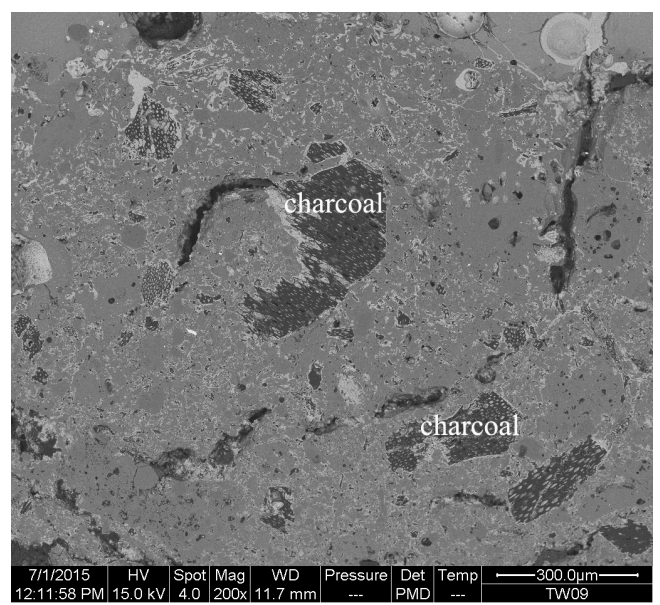

Figure 8.2: Charcoal fragments in Weishan crucible TW09.

19 " $\mathrm{MeO}^{\prime}$ stands for all fluxing metal oxides in the crucible composition, such as $\mathrm{Na}_{2} \mathrm{O}, \mathrm{K}_{2} \mathrm{O}$, $\mathrm{MgO}, \mathrm{CaO}$, and $\mathrm{MnO}$. 


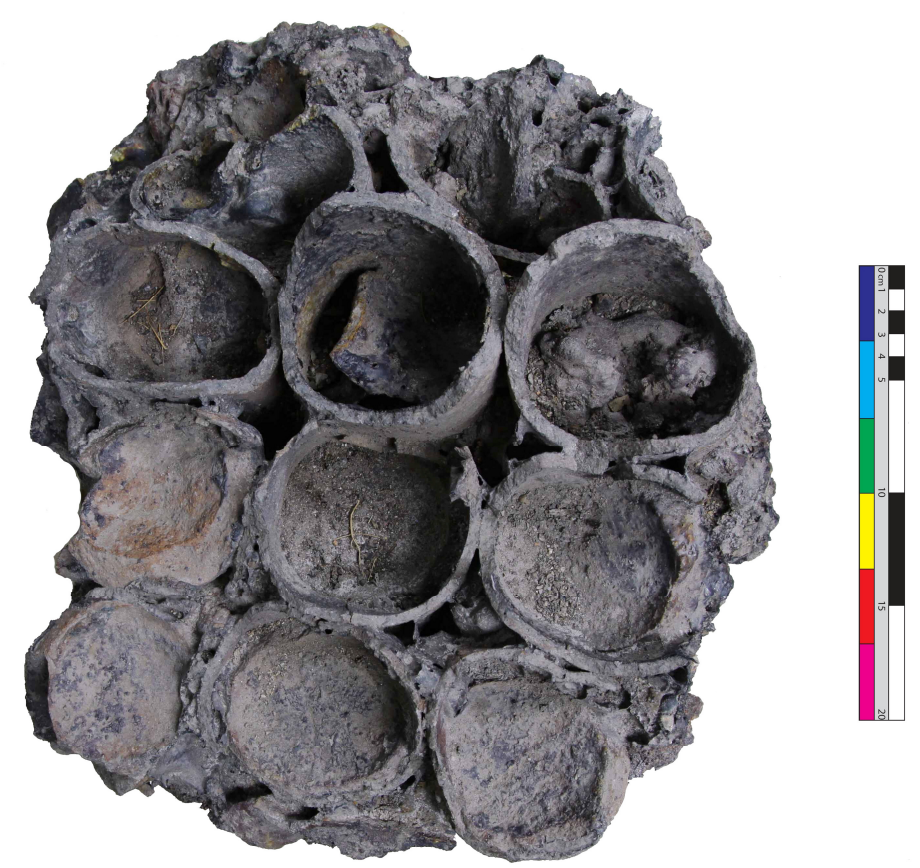

Figure 9: Sintered furnace base collected from Yanchuan.

\subsubsection{Iron reduction method for lead smelting}

The slag found at these sites are mostly in the middle part of the crucible. In general, the upper and lower ends of the mid-part crucible sherds are broken, the upper edge and lower bottom of the crucible missing, and the mid-part almost full of slag (Figure 5). Most of the slag is black or gray, some bluish, greenish, or whitish. Masses of quartz particles can be seen in most slag.

The slag samples from Yanchuan, Weishan, Guciyao, and Liaocheng sites are composed of a glassy matrix and inclusions of quartz particles (Figure 10.1). The Gangguantun slag samples are glassy with a quartz-rich layer on top. The glassy matrix mainly contains $\mathrm{SiO}_{2}, \mathrm{FeO}, \mathrm{Al}_{2} \mathrm{O}_{3}, \mathrm{CaO}$, and a small amount of $\mathrm{MgO}, \mathrm{K}_{2} \mathrm{O}, \mathrm{MnO}, \mathrm{ZnO}$, $\mathrm{PbO}$, and others (Table 5). The slag also contains a small amount of sulfide particles, that is, matte, mostly mixed phases of iron sulfide (FeS), lead sulfide ( $\mathrm{PbS})$, and $\mathrm{PbS}$ (Fe-Cu-S) (Figure 10.2). A few samples contain metallic lead particles, most of which have a layer of sulfide outside (Figure 10.3) or sulfide inclusion inside. Some lead particles in Yanchuan, Weishan, and Guciyao samples contain silver. The average silver content of Yanchuan lead particles is $4.5 \%$, strongly indicating that the lead smelted in these sites might have been used for silver extraction by cupellation. Some metallic iron particles were found in the samples from Yanchuan, Weishan, and Gangguantun. One 
piece of residual metallic iron in Yanchuan slag QYS-19 was $1.3 \mathrm{~cm}$ long and identified to be low-carbon steel with pearlite and ferrite. Another piece in Weishan slag TW10 was $0.5 \mathrm{~cm}$ long and identified to be wrought iron with ferrite structure (Figure 10.4).

According to their chemical composition, the slags all belong to the $\mathrm{Al}_{2} \mathrm{O}_{3}-\mathrm{CaO}-\mathrm{FeO}-$ $\mathrm{SiO}_{2}$ system, produced by lead smelting, with $\mathrm{CaO}$ and $\mathrm{FeO}$ as the main fluxes. In most samples, FeO is the dominant flux; however, some of the samples from Yanchuan and Gangguantun have higher $\mathrm{CaO}$ content (Figure 11). This most likely reflects differences in the gangue minerals, with more calcite $\left(\mathrm{CaCo}_{3}\right)$ in some samples; no other

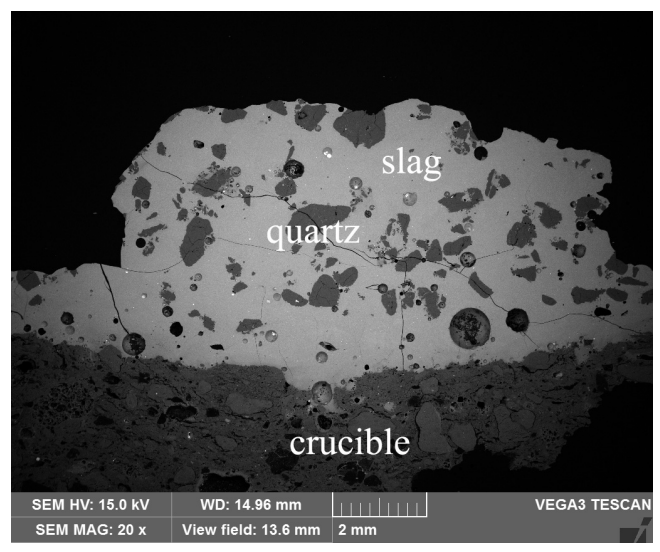

Figure 10.1: Quatz grains in Weishan crucible slag TW02.

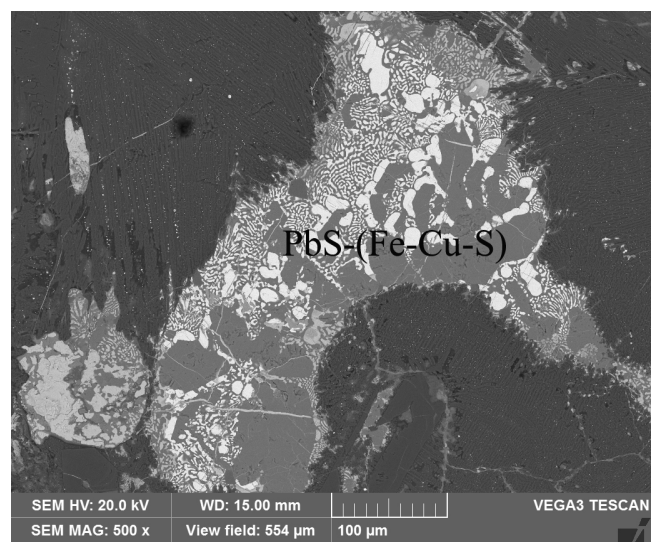

Figure 10.2: Matte PbS-(Fe-Cu-S) in Weishan crucible slag TW07.

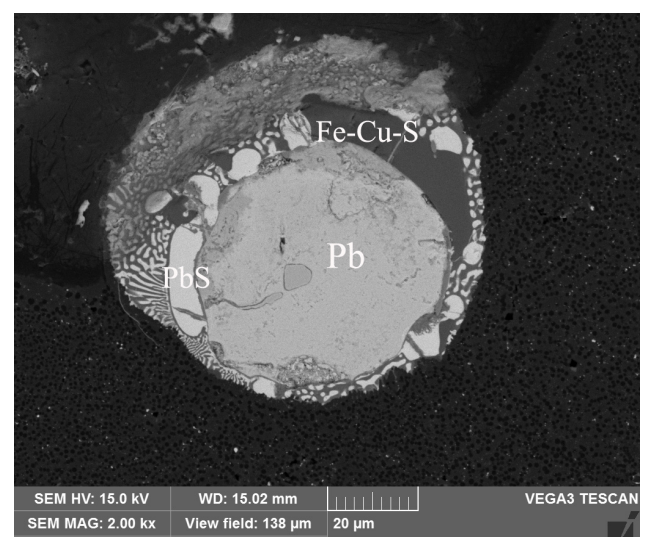

Figure 10.3: Lead particles with a circle of matte PbS-(Fe-Cu-S) around in Weishan crucible slag TW02.

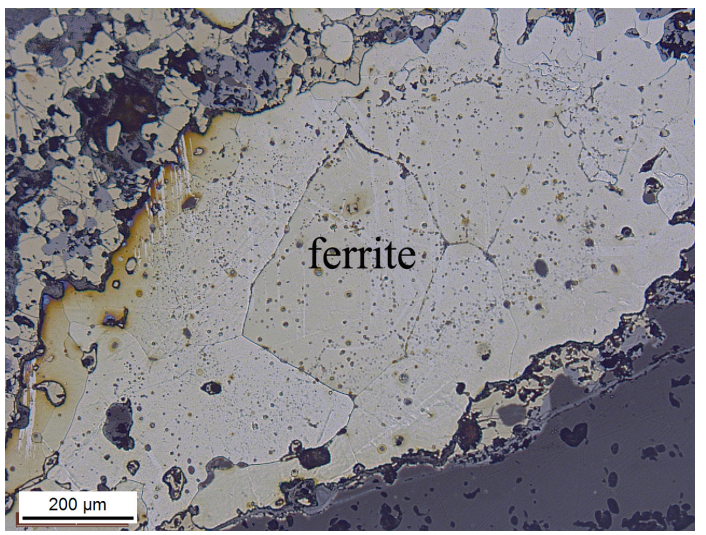

Figure 10.4: Residual iron piece with ferrite structure in Weishan crucible slag TW10. 
Table 5: Average bulk chemical composition of glassy matrix of slag from five sites (wt $\mathrm{t}$ )

\begin{tabular}{ccccccccccccccccc}
\hline Site & $\begin{array}{c}\text { Sample } \\
\text { number }\end{array}$ & $\mathrm{Na}_{2} \mathrm{O}$ & $\mathrm{MgO}$ & $\mathrm{Al}_{2} \mathrm{O}_{3}$ & $\mathrm{SiO}_{2}$ & $\mathrm{P}_{2} \mathrm{O}_{5}$ & $\mathrm{SO}_{3}$ & $\mathrm{~K}_{2} \mathrm{O}$ & $\mathrm{CaO}$ & $\mathrm{TiO}_{2}$ & $\mathrm{MnO}$ & $\mathrm{FeO}$ & $\mathrm{ZnO}$ & $\mathrm{BaO}$ & $\mathrm{PbO}$ \\
\hline $\begin{array}{c}\text { Yanchuan } \\
(\mathrm{QYS})(\mathrm{FeO})\end{array}$ & 12 & 0.2 & 1.7 & 9.2 & 49.7 & 0.4 & 0.9 & 2.1 & 7.9 & 0.4 & 0.4 & 22.5 & 1.1 & 0.6 & 2.9 \\
\hline $\begin{array}{c}\text { Yanchuan } \\
\text { (QYS) (CaO) }\end{array}$ & 7 & 0.2 & 3.0 & 10.2 & 56.2 & 0.3 & 0.4 & 2.5 & 19.9 & 0.6 & 0.0 & 3.7 & 0.8 & 1.4 & 0.9 \\
\hline $\begin{array}{c}\text { Weishan } \\
\text { (TW) }\end{array}$ & 12 & 0.4 & 2.0 & 7.8 & 51.8 & 0.6 & 1.6 & 2.2 & 6.4 & 0.5 & 1.1 & 20.9 & 2.5 & 0.7 & 1.9 \\
\hline \begin{tabular}{c} 
Guciyao (HY) \\
\hline $\begin{array}{c}\text { Liaocheng } \\
\text { (YX) }\end{array}$
\end{tabular} & 6 & 0.6 & 1.4 & 10.7 & 54.7 & 0.9 & 0.7 & 2.4 & 5.7 & 0.6 & 5.1 & 15.8 & 0.5 & 0.5 & 0.5 \\
\hline $\begin{array}{c}\text { Gangguantun } \\
\text { (GGT) (FeO) }\end{array}$ & 8 & 1.3 & 2.4 & 8.4 & 52.6 & 1.3 & 1.1 & 2.5 & 9.5 & 0.3 & 0.4 & 15.4 & 3.7 & 0.1 & 1.0 \\
\hline $\begin{array}{c}\text { Gangguantun } \\
\text { (GGT) (CaO) }\end{array}$ & 6 & 1.1 & 3.3 & 8.7 & 55.0 & 1.3 & 0.6 & 2.9 & 16.1 & 0.4 & 0.3 & 8.2 & 1.6 & 0.1 & - \\
\hline
\end{tabular}

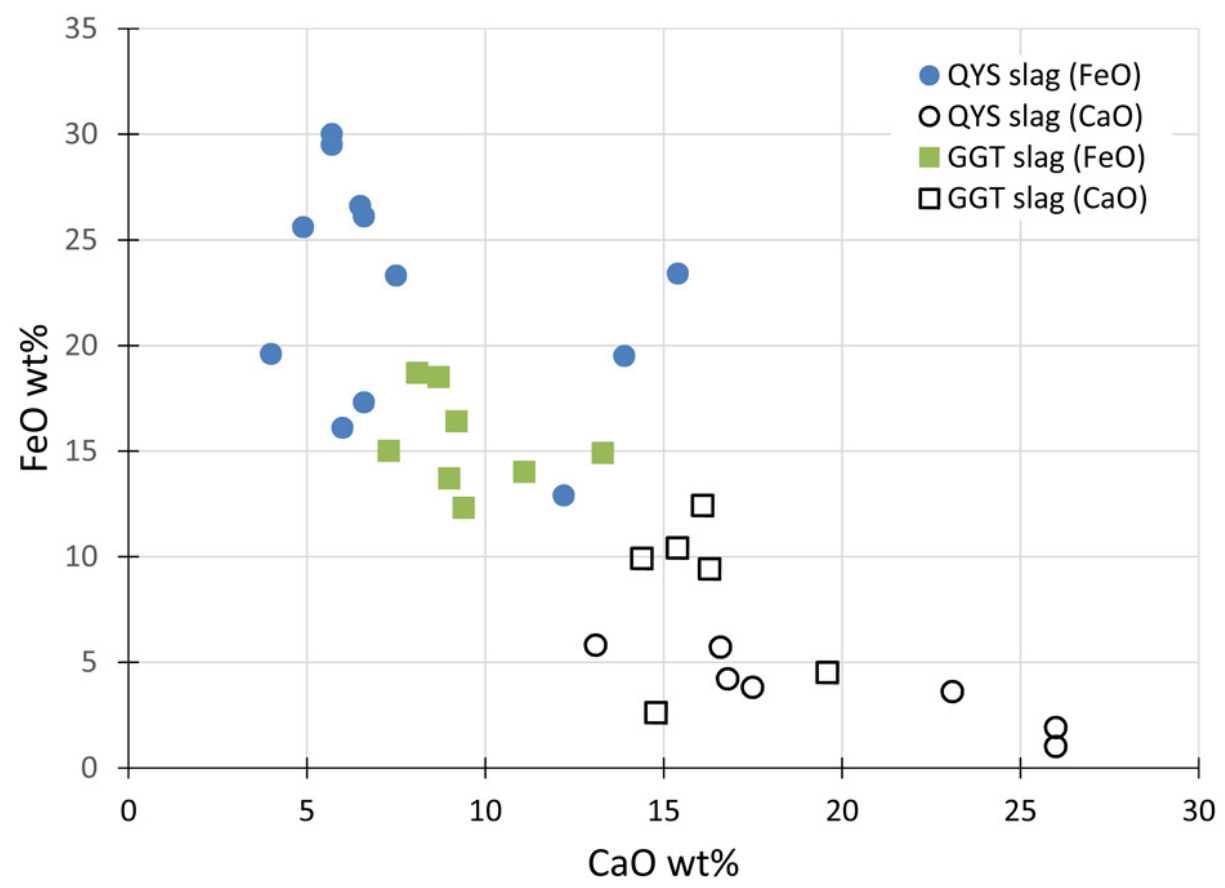

Figure 11: Scatter plot of $\mathrm{FeO}$ vs. $\mathrm{CaO}$ for crucible slag samples from Yanchuan (QSY) and Gangguantun (GGT), separated into those rich in $\mathrm{FeO}$ and $\mathrm{CaO}$, respectively. The two oxides substitute each other as flux for silica, leading to the negative correlation between the two. 
difference can be noted though in the process itself. Laboratory re-melting experiments of Yanchuan slag indicate a furnace temperature of around $1200^{\circ} \mathrm{C}$ for this technology (Liu et al. 2019, 79). As can be seen in Figure 12, only the melting temperature of the quartz-free slag from Liaocheng is in the order of $1200^{\circ} \mathrm{C}$ in the pure ternary diagrams; all other samples fall into the temperature region of $1400^{\circ} \mathrm{C}$ to $1500^{\circ} \mathrm{C}$. While the very refractory crucibles would probably have withstood this temperature, it is unlikely that such temperatures were ever reached. Instead, the presence of multiple fluxing oxides, combined here into a single term for $\mathrm{FeO}$, lowers the real melting temperature of the slag by a few hundred degrees. Thus, the composition of the slag as plotted into the ternary phase diagram is consistent with the reported furnace temperatures of $1200^{\circ} \mathrm{C}$, while the elevated silica content reflects the presence of countless quartz particles in the molten slag, saturating it in silica.

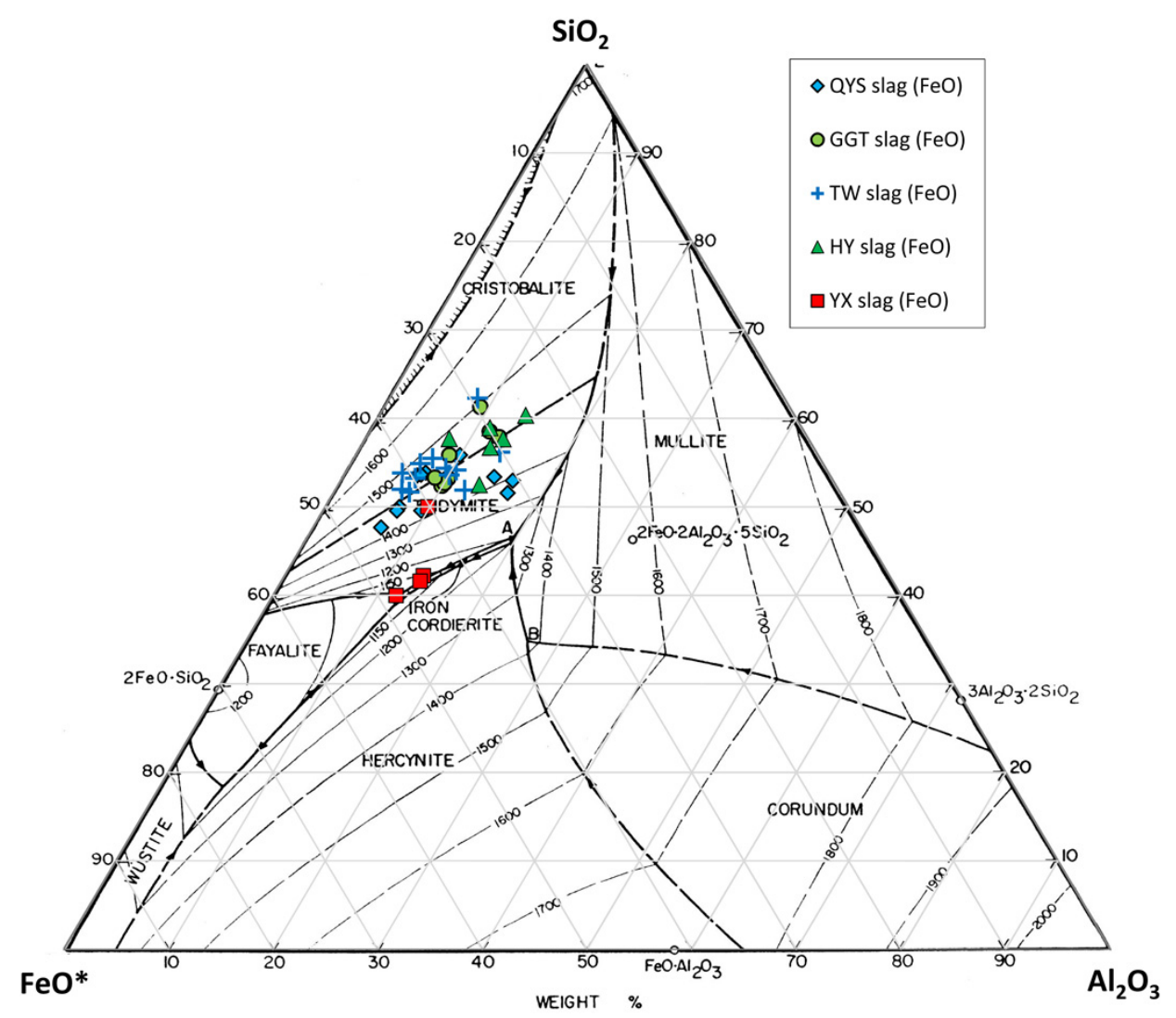

Figure 12: Projection of crucible slag compositions from five sites into the $\mathrm{SiO}_{2}-\mathrm{Al}_{2} \mathrm{O}_{3}$ $(\mathrm{FeO}+\mathrm{MeO})$ ternary phase diagram (after Muan 1957). A few slags plot into the ternary eutectic region (YX slag from Liaocheng); these have no free silica inclusions. All other slags have numerous quartz inclusions and plot towards elevated silica compositions, reflecting the saturation of the melt in this compound as well as possibly the inadvertent inclusion of some quartz into the analyzed sample area. 
According to the content of $\mathrm{FeO}, \mathrm{PbO}$, and sulfur in the lead smelting slag of these sites, the lead was smelted with the iron reduction method (Liu et al. 2018). Slag in lead smelting crucibles occupies most of the space. Given the metallic iron found in the slag, the reducing agent added in the crucible is not carbonaceous, but metallic iron. In order to verify the feasibility of lead smelting by the iron reduction method, Liu Siran simulated the lead smelting technology used in Yanchuan in the laboratory (Liu et al. $2019,80-81$ ). In the experiment, slag with quartz inclusions formed in the central part of the crucible, with a layer of matte underneath and lead metal in the lowest part. No large lead particles were left in the slag. The experiment shows that lead sulfide can be well reduced with metallic iron, with the metallic lead easily separated from the slag.

\section{Discussion on related issues}

\subsection{Technical features}

With the review of historical records, the recent discovery of smelting sites and the ongoing analysis of metallurgical remains, a better understanding of traditional Chinese crucible smelting technology is emerging. In general, the technology takes the following steps: First, cylindrical crucibles are produced by molding, using kaolinitic refractory clay with inclusions of quartz and coal (or charcoal), either as natural part of the clay, or added as temper. A rectangular furnace is built, with crucible fragments piled at the furnace base as furnace bars. Then the lead ore, consisting of galena and gangue such as quartz and calcite, and scrap metal iron are added into the crucibles, which are placed side by side in the furnace. Some differences exist mostly in the nature of the ore, which varies not only among different smelting sites, but even within individual sites, as seen for instance in Yanchuan or Gangguantun. Coal is used as fuel and the furnace is heated to $1200^{\circ} \mathrm{C}$ for several hours. After smelting, the crucibles are broken to obtain the lead at the bottom of the crucible. Silver, if contained in the lead, can then be further extracted by cupellation. The crucible lead smelting technology is thus mainly characterized by the adoption of crucibles, heated in the smelting furnace fueled by coal; the mixture of kaolinite and coal to make cylindrical externally heated crucible; and the application of the iron reduction method to smelt lead sulfide.

This technology has a key advantage in that it is adapted to smelt lead, with mineral coal used as fuel to fire the furnaces, but not as the reducing agent. Despite the limited scale of individual crucibles, yielding only a few kilograms of metal at a time, the technology can be scaled up for mass production. The indigenous method in the twentieth century used the rectangular furnaces that had a capacity of dozens to hundreds of crucibles, with many ventilation holes at the bottom of the furnace (Figure 1). Here, the fuel is blown by natural air, while in the Qing dynasty a bellow was used to 
provide the blast for crucible lead smelting in Gansu (IQHRUC and TRSCPSHDARUC 1983, 382-383). We argue that the choice of fuel use was a key reason for the adoption of this technology. Current archaeological findings suggest two major traditional technologies were applied for lead smelting in ancient China: one is the crucible lead smelting technology employed in northern China since the Liao-Jin-Yuan periods, fueled by coal; the other is the furnace lead smelting technology in southern China, known at least since the Tang-Song periods, and fueled by charcoal. Compared with furnace technology, the crucible technology separates the fuel combustion from ore reduction. Not only is strong reducibility ensured in the crucible, but lead sulfide can be smelted without the need to first roast the ore, and coal can be utilized as fuel, and natural air draft as the blast power. The use of crucible lead smelting in northern China can be mainly explained by the use of fuel. Since the Xia, Shang, and Zhou periods, ancient Chinese metallurgy had been using charcoal as fuel to smelt copper, iron, and other metals. In the Song dynasty, the shortage of charcoal resources in northern China resulted in coal becoming the standard fuel used in households and being also widely used in the porcelain manufacturing industry (Golas 1999, 195; Li, Wu, and $\mathrm{Lu} \mathrm{2007,}$ 277-281). However, there are some problems with coal as fuel: coal has a decreased strength at high temperatures and is not suitable for use in tall blast furnaces. Furthermore, most coal contains impurities such as sulfur and ash that will get into the product and substantially affect the quality of the metal. Crucible lead smelting physically separated the fuel from the ore and metal charge, preventing this contamination from happening. It is therefore possible that this technology appeared due to the shortage of charcoal resources in northern China, making the use of coal as fuel an alternative (Liu et al. 2019). In the Ming and Qing periods, crucibles were also used for zinc and even for iron smelting, also fueled by coal.

To achieve this indirect heating of the charge, the crucible had to be heated from outside and made of kaolinitic refractory clay strong enough to withstand the high operating temperatures. In the history of ancient Chinese metallurgy, as elsewhere, the earliest crucibles were shallow, open copper melting crucibles in the Xia-Shang-Zhou periods. They were heated internally, made of material that was less dense and not particularly fire-resistant, and the wall was thick. Some of the crucibles were mixed with plant fibers to provide a sound heat insulation. No later than the Eastern Han dynasty (25-220), cylindrical crucibles with small openings came into being, which were heated externally. By the Tang dynasty, externally heated crucibles had been also used to melt copper and iron. Since the Liao-Jin-Yuan periods, cylindrical crucibles had been used for lead smelting, and then for zinc and iron smelting in the Ming and Qing dynasties (Zhou, Liu, and Chen 2016). The fabric of externally heated crucibles is dense, fire-resistant, thin walled, and with good thermal conductivity, so that heat can be transferred from the outside to the inside. The lead smelting crucibles are made of 
kaolinitic refractory clay mixed with coal (charcoal). Other crucibles of similar materials include the ones from a Han tomb in Jili District, Luoyang City (He et al. 1985), and the ones for melting iron in the Yuan dynasty at Chucun, Xingyang City (Compilation Group of History of Chinese Metallurgy and Zhengzhou Museum 1984). It is also recorded in "Metallurgy: Coins" (Yezhu: Qian 冶铸 • 钱) in The Exploitation of the Works of Nature that "carbon powder" (tanmo 炭末) was used to make the copper melting crucible (Song [1637] 2008, 169). The crucible mixed with coal (charcoal) is presumably similar to the graphite crucibles in medieval Europe (Martinón-Torres et al. 2008). Characterized by high fire resistance, thermal shock resistance, thermal conductivity, and chemical stability, the material is remarkably rare in the ceramic history of China and even of the world.

Finally, the crucible lead smelting technology directly reduces the lead sulfide ore with metallic iron. Sulfide ores were usually roasted for desulfurization, then converted into oxide ores, and then reduced by carbon reductant. With the crucible smelting technology, lead can be directly reduced without ore roasting, which avoids the volatilization of lead in the roasting process, making gold, silver, and other precious metals more easily enriched in lead. The iron reduction method used in crucible lead smelting may have been borrowed from furnace smelting. Many furnace sites for lead smelting have been found in Shanggao, Shangrao, Dexing, and other places in Jiangxi Province. The Baojia site in Shangrao, which was used for lead smelting by reduction, may date back to the Tang dynasty (Liu 2015). However, iron reduction crucible lead smelting calls for a certain amount of metallic iron, which is more expensive than the carbon reductant process. In the trial smelting in Jingyuan of Gansu Province in the Qing dynasty, the metallic iron used was $43 \%$ of the weight of lead ore, accounting for $28 \%$ of the total cost (IQHRUC and TRSCPSHDARUC 1983, 382-383). In the twentieth century, the amount of iron used in traditional crucible lead smelting ranged from 30$40 \%$ of the weight of lead ore to $10 \%$, generally in the form of scrap iron, or sometimes iron ore (Table 2). In the Liao-Jin-Yuan periods, the high production of iron in northern China may have contributed to the lower cost of using iron as a reducing agent in lead smelting. Moreover, the smelted lead can be further used to extract silver, which improves the value of the product.

\subsection{Technical origin and development}

The earliest Chinese crucible lead smelting sites roughly date back to the Liao-Jin-Yuan periods, as existing data and investigation suggest. Their exact date is not clear since most of the sites have not been scientifically excavated. Most of the crucible lead smelting sites are co-located with porcelain kilns. No clear stratigraphic relationship has been found between the discovered lead smelting crucibles and the kiln deposits, 
making it impossible to determine their specific dates. Only the crucibles at the Yanchuan site are clearly superimposed on the late-Jin kiln deposits, putting its date to the late Jin dynasty. Some sites are approximately dated to be around the Liao-Jin or Liao-Jin-Yuan periods. Whether they go back as early as the Liao dynasty has not been confirmed, but this possibility cannot be ruled out. As is known, most of the Songdynasty silver-lead ores exploited lay in the south, such as Zhejiang, Fujian, and Jiangxi. Since the beginning of the Liao dynasty, the government turned to exploit northern silver-lead resources in Hebei, Beijing, Liaoning, and Inner Mongolia. Therefore, the crucible lead smelting activities carried out in northern China may be largely related to the promoted development of silver-lead mines in the Liao period.

Remarkably similar cylindrical crucibles dating to the same period are known from Akhsiket in eastern Uzbekistan and Merv in Turkmenistan (Rehren and Papakhristu 2000). In Akhsiket, crucible steel production reached industrial scale during the tenth and eleventh centuries $\mathrm{CE}$, and millions of crucible sherds from this period were preserved (Figure 13). Their cylindrical shape with a hemispherical bottom was standardized to an internal diameter of $8 \mathrm{~cm}$ and a total height of just under $30 \mathrm{~cm}$. Their fabric is compositionally very similar to the Chinese lead smelting crucible fabrics based on a local kaolin-coal deposit in the Tianshan Mountains in Akhsiket's hinterland. The mid-parts of the crucibles are full of glassy slag, some with quartz inclusions. Like their Chinese counterparts, the Akhsiket crucibles were formed around a wooden mold with a cloth covering to facilitate release (Alipour, Gleba, and Rehren 2011). The only difference to the Chinese crucibles is the inevitable presence of a lid in the Akhsiket crucibles, necessary to maintain the strongly reducing conditions needed for crucible steel making. Given the geographic extent of the Liao dynasty, which reached the westernmost part of China, and the situation of Akhsiket in eastern Uzbekistan along a main branch of the Silk Road, it is quite feasible that the two crucible technologies have a common technological origin, based on similar raw material availability and the shared requirement to separate the source of heat from the reaction chamber of the actual metallurgical process.

Due to the lack of historical records and archaeological findings, when and where the crucible lead smelting technology began remains unknown. Current data suggest that it probably originated during the Liao-Jin-Yuan periods and was used at least until the Qing period, and even into the late twentieth century. At present, no evidence of crucible lead smelting from the Ming period has been found, but there are indications that crucible lead smelting might have existed in northern China during the Qing period. In the Qing dynasty, Guizhou Province was the largest lead producer, followed by provinces of Yunnan, Sichuan, Hunan, and Guangxi in the south, at a time when Shaanxi, Shanxi, Zhili (now parts of Beijing, Hebei, and Inner Mongolia), and Gansu (now Gansu and Ningxia) in the north produced lead as well but with low yield (Ma 
2013, 294-299; IQHRUC and TRSCPSHDARUC 1983). According to the records about Jingyuan lead smelting in the Qianlong period, this technology is likely to be mature in Gansu and Ningxia. In addition, two crucible lead smelting sites were found in Yicheng County, Shanxi Province; according to the local gazetteers, it was built no later than the late Qing dynasty (Cheng et al. 2012). Therefore, the northern part of China probably still practiced the crucible technology to smelt lead in the Qing dynasty. Even in the twentieth century, the technology was still used in northern regions such as Beijing and Inner Mongolia, in addition to Hunan Province. But the crucible lead smelting technology adopted in Shuikoushan, Changning County, Hunan Province might not

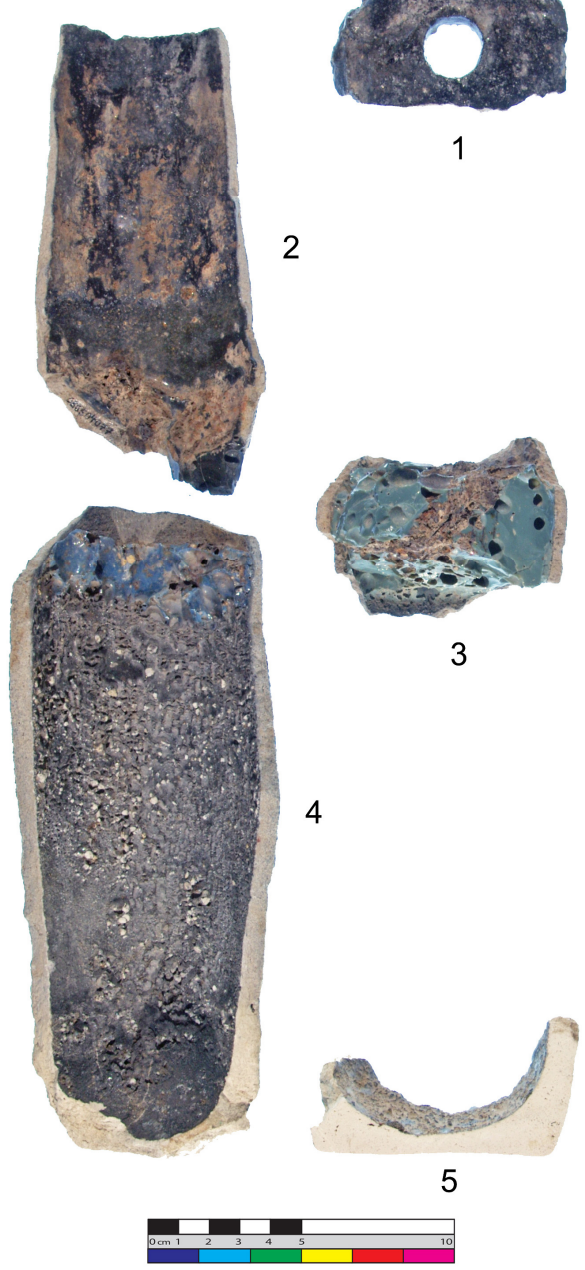

Figure 13: Steel-making crucibles from Akhsiket (photo by Stuart Laidlaw).

1. Lid; 2. Upper part; 3. Mid-part with slag; 4. Lower part; 5. Bottom. 
have been passed down locally. In the early twentieth century, Shuikoushan used a local method taken from nearby Guiyang County to produce zinc and lead, which was inherited from the Qing period, while furnaces were used for lead smelting (Cao 1917).

At present, no crucible lead smelting site has been found outside China, with the only historical record of it found in India. In the early fourteenth century (about the beginning of the Yuan dynasty), Thakkura Pherū, an Indian scholar, recorded the crucible lead smelting technology with iron reduction. It was clearly noted that each furnace was filled with thirty crucibles with lead ore and iron mixed in them for lead smelting as illustrated in his book (Figure 14) (Dube 2006). Obviously different features can be recognized of the technology illustrated in the book, compared with the crucible technology adopted in China: the crucible is conical with larger top part and smaller bottom part, fewer crucibles were contained in each furnace, and air was blown by manpower. The relationship between China's and India's crucible lead smelting technology remains to be further studied.

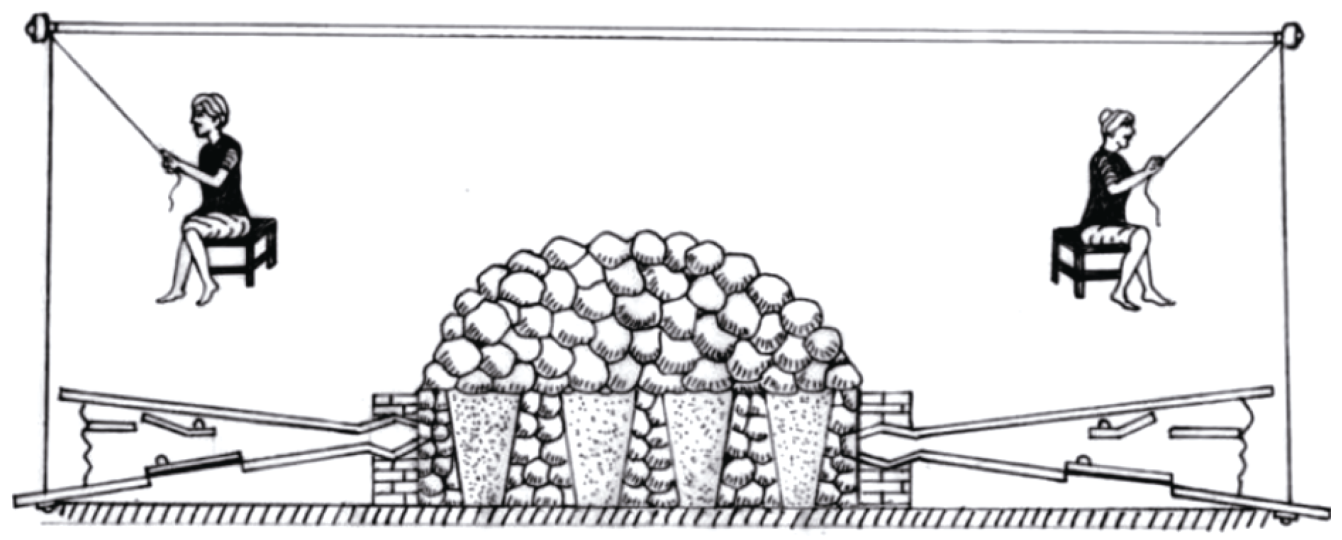

Figure 14: Indian crucible lead smelting furnace recorded by Thakkura Pherū (Dube 2006, 20).

\section{Conclusion}

Based on the review of historical records and scientific investigation of the Liao-JinYuan smelting sites and the smelting remains, this paper explains the technical process and reconstructs the lead smelting technology using crucibles and iron reduction. It is found that the traditional crucible lead smelting technology in China uses alumina-rich refractory clay mixed with coal or charcoal to make cylindrical crucibles and directly reduces lead sulfide with metallic iron as reducing agent, fueled externally by coal, in a rectangular furnace with natural air draft. This technology is different from lead smelting in a hearth or furnace. With the exception of a record in India from the fourteenth century, documentation of the process has not been found outside China, 
signaling an important position in the world metallurgical history as a sophisticated and environmentally adapted process that was used extensively for more than half a millennium. Smelting lead with crucibles is very similar to smelting zinc, which is also exclusive to China and India. The earliest and longest-lasting among the two, crucible lead smelting originated in northern China, was adopted in the Liao-Jin-Yuan periods onward, and used until the twentieth century.

Due to the limitations of the historical records, the in-depth study of crucible lead smelting technology needs more archaeological research and scientific analysis. So far, few of the crucible lead smelting sites have been archaeologically excavated and their date remains unclear. Related finds, such as the furnaces used for crucible lead smelting, metallic lead, intermediate product matte, and silver cupellation remains have not been discovered yet, and the relationship between the sites and porcelain kilns is unclear. More archaeological work and laboratory research is needed in the future.

\section{Acknowledgments}

This research was completed by the research team including Prof. Chen Jianli, Dr. Zhou Wenli, Dr. Liu Siran, and Dr. Liu Haifeng. It was further developed by Prof. Thilo Rehren with the interpretation of analytical data and the discussion of technical origin related to steel-making crucibles. We gratefully acknowledge the help of all the archaeologists who kindly provided samples, information, and feedback. They are Vice Director Huang Xin from the Institute of Archaeology of Heibei Province, Director Chen Yongzhi from the Inner Mongolia Museum, Vice Director Liu Yan from the Institute of Archaeology of Shanxi Province, Xiao Juntao from the Institute of Archaeology of Liaoning Province, Prof. Qin Dashu, Associate Profs. Cui Jianfeng and Liu Wei from School of Archaeology and Museology, Peking University. We also appreciate Mr. Luo Shengqiang's help with drawing the crucible bottoms.

\section{References}

Alipour, Rahil, Margarita Gleba, and Thilo Rehren. 2011. “Textile Templates for Ceramic Crucibles in Early Islamic Akhsiket, Uzbekistan." Archaeological Textiles Newsletter 53:15-27.

Bayley, J., and Th. Rehren. 2007. "Towards a Functional and Typological Classification of Crucibles." In Metals and Mines: Studies in Archaeometallurgy, edited by S. La Niece, D. Hook, and P. T. Craddock, 46-55. London: Archetype.

Beijing Public-Private Joint Smelting Plant. 1958. “Tufa zilaifeng lu tilian tong qian jin yin” 土法 自来风炉提炼铜铅金银 [Extraction of Copper, Lead, Gold, and Silver by Indigenous Method with Self-Blast Furnace]. Beijing: Metallurgical Industry Press.

BMDIIMAR (Bureau of Metallurgy of Department of Industry of Inner Mongolia Autonomous Region). 1958. Tufa lianqian 土法炼铅 [Lead Smelting by Indigenous Method]. Hohhot: Inner 
Mongolia People's Press.

Cao, Ren 曹仁. 1917. “Tufa yexin shu” 土法冶锌术 [Indigenous Method of Zinc Smelting]. Kuangye zazhi 矿业杂志 [Journal of Mining], no. 2, 93-97.

Chen, Guofa 陈国发. 1992. Zhongjinshu yejin xue 重金属冶金学 [Heavy Metal Metallurgy]. Beijing: Metallurgical Industry Press.

Cheng, Qun 程群, Li Yanxiang 李延祥, Li Jianxi 李建西, Dong Lijun 董利军, and Wang Yingze 王迎泽. 2012. “Shanxi Sheng Yicheng Xian dongnan liangchu yizhi de luzha yanjiu” 山西省翼 城县东南两处遗址的炉渣研究 [A Study of Slag from Two Archaeological Sites Southeast of Yicheng]. Zhongguo Guojia Bowuguan guankan 中国国家博物馆馆刊 [Journal of National Museum of China], no. 11, 132-140.

The Chinese Ceramic Society, ed. 1982. Zhongguo taoci shi 中国陶瓷史 [History of Ceramics in China]. Beijing: Cultural Relics Publishing House.

CGMBZSP (Compilation Group of Metallurgy Brochure of Zhuzhou Smelting Plant). 1973. Qian de shengchan 铅的生产 [Production of Lead]. Changsha: Hunan People's Publishing House.

Compilation Group of History of Chinese Metallurgy 中国冶金史 [Zhongguo yejin shi], and Zhengzhou Museum. 1984. "Xingyang Chucun Yuandai zhuzao yizhi de shijue yu yanjiu” 䓠 阳楚村元代铸造遗址的试掘与研究 [Trial Excavation and Research of Yuan Dynasty Foundry Site in Chucun, Xingyang City]. Zhongyuan wenwu 中原文物 [Cultural Relics of Central China], no. 1, 60-70, 104-105.

DACHCHNU (Department of Archaeology, College of History and Culture, Hebei Normal University), and CRPMIKC (Cultural Relics Protection and Management Institute of Kangbao County). 2014. “Hebei Sheng Kangbao Xian Xitucheng chengzhi kaogu diaocha jianbao" 河北 省康保县西土城城址考古调查简报 [Brief Report on Archaeological Investigation of Xitucheng Site, Kangbao County, Hebei Province]. Caoyuan wenwu 草原文物 [Steppe Cultural Relics], no. 1, 63-77, 162.

DNMSNIT (Department of Nonferrous Metal Smelting, Northeast Institute of Technology). 1960. Qian yejin xue 铅冶金学 [Lead Metallurgy]. Beijing: Metallurgical Industry Press.

DNMSNIT. 1976. Qian yejin 铅冶金 [Lead Metallurgy]. Beijing: Metallurgical Industry Press.

Dube, R. K. 2006. "The Extraction of Lead from Its Ores by the Iron-Reduction Process: A Historical Perspective." JOM 58 (10): 18-23.

Glumac, Petar, and Judith Todd. 1987. "New Evidence for the Use of Lead in Prehistoric SouthEast Europe." Archeomaterials, no. 2, 29-37.

Golas, P. J., 1999. Chemistry and Chemical Technology: Mining. Vol. 5, part 13 of Science and Civilisation in China. Cambridge: Cambridge University Press.

Guo, Xun 郭珣. 2018. “Liaoyang Gangguantun yaozhi ganguo lianqian jishu chubu yanjiu” 辽阳 江官屯窑址坩埚炼铅技术初步研究 [Preliminary Research on the Crucible Lead Smelting Technology in Gangguantun Klin in Liaoyang City]. Undergraduate thesis, Beijing Union University.

Han, Rubin 韩汝玢, and Ke Jun 柯俊. 2007. Zhongguo kexue jishu shi: Kuangye juan 中国科学技术 史 - 矿冶卷 [History of Science and Technology in Pre-modern China: Mining and Metallurgy]. Beijing: Science Press.

Hansen, Svend, Ignacio Montero-Ruiz, Salvador Rovira, Daniel Steiniger, and Meda Toderas. 
2019. "The Earliest Lead Ore Processing in Europe. 5th Millennium BC Finds from Pietrele on the Lower Danube." PLoS ONE 14 (4): e0214218.

He, Tangkun 何堂坤. 2009. Zhongguo gudai jinshu yelian he jiagong gongcheng jishu shi 中国古代金 属治炼和加工工程技术史 [The History of Metal Smelting and Processing Engineering Technology in Ancient China]. Taiyuan: Shanxi Education Publishing House.

He, Tangkun, Lin Yulian 林育炼, Ye Wansong 叶万松, and Yu Fuwei 余扶危. 1985. “Luoyang ganguo fuzhuo gang de chubu yanjiu” 洛阳坩埚附着钢的初步研究 [Preliminary Research on the Steel Attached to the Crucible Discovered in Luoyang]. Ziran kexueshi yanjiu 自然科学史研 究 [Studies in the History of Natural Sciences] 4 (1): 59-63, 100.

Hua, Jueming 华觉明. 1999. Zhongguo gudai jinshu jishu: Tong he tie zaojiu de wenming 中国古代金 属技术——铜和铁造就的文明 [The Metal Technology of Ancient China: Civilization Created by Copper and Iron]. Zhengzhou: Elephant Press.

Huang, Xin 黄信, Liang Liang 梁亮, Zhang Shouyi 张守义, and Zhang Chunchang 张春长. 2008. “Chengde diqu Liao Jin Yuan shiqi chengzhi kancha baogao" 承德地区辽金元时期城址勘查报 告 [Investigation Report of Chengde City in Liao, Jin, and Yuan Periods]. Wenwu shijie 文物世 界 [World of Antiquity], no. 5, 11-26.

IQHRUC (Institute of Qing History of Renmin University of China), and TRSCPSHDARUC (Teaching and Research Section of Chinese Political System History of Department of Archives, Renmin University of China). 1983. Qingdai de kuangye 清代的矿业. [Mining Industry in the Qing Dynasty]. Beijing: Zhonghua Book Company.

Li, Jinghua 李京华. 2007. Yejin kaogu 治金考古 [Archaeometallurgy]. Beijing: Cultural Relics Publishing House.

Li, Jinyao 李进尧, Wu Xiaoyu 吴晓显, and Lu Benshan 卢本珊. 2007. Zhongguo gudai jinshu kuang he meikuang kaicai gongcheng jishu shi 中国古代金属矿和煤矿开采工程技术史 [Mining Engineering History of Metal and Coal Deposits in Ancient China]. Taiyuan: Shanxi Education Publishing House.

Li, Xingzheng 李兴正. 1996. “Qiantan tufa (ganguolu) lianqian” 浅谈土法 (坩埚炉) 炼铅 [On Lead Smelting by Indigenous Method (with Crucible)]. Sichuan youse jinshu 四川有色金属 [Sichuan Nonferrous Metals], no. 1, 24-26.

Li, Yanxiang, and Zhou Weirong 周卫荣. 2000. “Guangxi Hexian Tieshiling yizhi Songdai xi qian ji hanxi tiexian yelian jishu chubu yanjiu” 广西贺县铁屎岭遗址宋代锡铅及含锡铁钱冶炼技术初 步研究 [Preliminary Study on Smelting of Tin, Lead, and Tin-Contained Iron Coin at the Tieshiling site in He County, Guangxi in the Song Dynasty]. Youse jinshu 有色金属 [Nonferrous Metals] (52) 2: 91-95.

Liu, Haifeng 刘海峰, and Chen Jianli 陈建立. 2019. “Jindai Litongjian zhuqian qianliao yu chengben yanjiu" 金代利通监铸钱铅料与成本研究 [The Raw Material and Manufacturing Cost of the Litong Mint of the Jin Dynasty]. Ziran bianzhengfa tongxun 自然辩证法通讯 [Journal of Dialectics of Nature] 41 (12): 6-10.

Liu, Siran. 2015. Gold and Silver Production in Imperial China: Technological Choices in Their SocialEconomic and Environmental Settings. PhD diss., University College London.

Liu, Siran 刘思然, Chen Jianli, Xu Changqing 徐长青, and Thilo Rehren. 2016. “Jiangxi Shangrao Baojia jinyin yelian yizhi de yejin kaogu diaocha yu yanjiu” 江西上饶包家金银冶炼遗址的冶金 
考古调查与研究 [The Investigation and Research of Archaeometallurgy on the Smelting Sites of Gold and Silver in Baojia, Shangrao, Jiangxi Province]. Nanfang wenwu 南方文物 [Cultural Relics in Southern China], no. 1, 128-137.

Liu, Siran, Chen Jianli, Xu Changqing, and Thilo Rehren. 2018. “Jiangxi Shanggao Mengshan yizhi gudai yin qian yelian jishu yanjiu” 江西上高蒙山遗址古代银铅冶炼技术研究 [A Study of Ancient Silver and Lead Smelting at the Shanggao Mengshan Site in Jiangxi]. Jianghan kaogu 江 汉考古 [Jianghan Archaeology], no. 1, 103-113.

Liu, Siran, Thilo Rehren, Dashu Qin, Jianli Chen, Wenli Zhou, Marcos Martinón-Torres, Xin Huang, and Wei Qian. 2019. "Coal-fuelled Crucible Lead-Silver Smelting in 12th-13th Century China: A Technological Innovation in the Age of Deforestation." Journal of Archaeological Science 104:75-84.

Liu, Siran, Thilo Rehren, Jianli Chen, Changqing $\mathrm{Xu}$, Pira Venunan, David Larreina-Garcia, and Marcos Martinón-Torres. 2015. "Bullion Production in Imperial China and Its Significance for Sulphide Ore Smelting World-wide." Journal of Archaeological Science 55:151-165.

Ma, Qi 马琦. 2013. Guojia ziyuan: Qingdai Dian tong Qian qian kaifa yanjiu 国家资源: 清代滇铜黔 铅开发研究 [National Resources: Research on the Exploitation of Copper in Yunnan and Lead in Guizhou in the Qing Dynasty]. Beijing: People's Publishing House.

Martinón-Torres, M., I. C. Freestone, A. Hunt, and Th. Rehren. 2008. "Mass-Produced Mullite Crucibles in Medieval Europe: Manufacture and Material Properties." Journal of American Ceramic Society 91 (6): 2071-2074.

Martinón-Torres, M., Th. Rehren, and I. C. Freestone. 2006. "Mullite and the Mystery of Hessian Wares." Nature 444 (November 23): 437-438.

Muan, A. 1957. "Phase Equilibria at Liquidus Temperatures in the System Iron Oxide- $\mathrm{Al}_{2} \mathrm{O}_{3}-\mathrm{SiO}_{2}$ in Air Atmosphere." Journal of the American Ceramic Society 40 (4): 121-133.

National Cultural Heritage Administration, ed. 2000. "Hebei Jingxingyao Hedongpo yaoqu" 河 北井陉窑河东坡窑区 [Hedongpo Kiln in Jingxing County, Hebei Province]. In 1998 Zhongguo zhongyao kaogu faxian 1998 中国重要考古发现 [Important Archaeological Discoveries in China 1998], 88-90. Beijing: Cultural Relics Publishing House.

Peng, Rongqiu 彭容秋. 2004. Qian yejin 铅冶金 [Lead Metallurgy]. Changsha: Zhongnan University Press.

Qi, Yanxin 齐岩辛, Zou Xia 邹霞, Chen Meijun 陈美君, and Xu Honggen 许红根. 2012. “Suichang gudai yinkuang yizhi caikuang lishi ji kuangye gongyi tantao” 遂昌古代银矿遗址采 矿历史及矿业工艺探讨 [A Discussion on the Mining History and the Mining Technology of the Ancient Silver Site in Suichang County]. Keji tongbao 科技通报 [Bulletin of Science and Technology] (28) 1: 68-73.

Qinghai Ministry of Metallurgical Industry. 1958. Tufa lianqian 土法炼铅 [Lead Smelting by Indigenous Method]. Xining: Qinghai People's Press.

Rehren, Thilo. 2003. "Crucibles as Reaction Vessels in Ancient Metallurgy." In Mining and Metal Production Through the Ages, edited by P. T. Craddock and J. Lang, 207-215. London: British Museum Press.

Rehren, Thilo, and Olga Papakhristu. 2000. “Cutting Edge Technology - The Ferghana Process of Medieval Crucible Steel Smelting." Metalla (Bochum) 7 (2): 55-69.

Song, Yingxing 宋应星. [1637] 2008. Tiangong kaiwu 天工开物 [The Exploitation of the Works of 
Nature], translated and annotated by Pan Jixing 潘吉星. Shanghai: Shanghai Ancient Books Publishing House.

Tan, Derui 谭德睿, and Sun Shuyun 孙淑云, eds. 2007. Zhongguo chuantong gongyi quanji: Jinshu gongyi 中国传统工艺全集 - 金属工艺 [Complete Collection of Traditional Chinese Handicrafts: Metalworking]. Zhengzhou: Elephant Press.

Wu, Kexian 吴克贤, Fan Shuhai 㚞书海, Meng Fanfeng 孟繁峰, Zhao Ziying 赵子英, and Xu Yongjiang 徐永江. 2007. “Hebei Funing Xian Panzhuang gu ciyao yizhi diaocha jianbao” 河北 抚宁县潘庄古瓷窑遗址调查简报 [Survey of Ancient Kiln Sites at Panzhuang in Funing County, Hebei]. Huaxia kaogu 华夏考古 [Huaxia Archaeology], no. 2, 39-51, 156-159.

Xia, Xiangrong 夏湘蓉, Wang Genyuan 王根元, and Li Zhongjun 李仲均. 1980. Zhongguo gudai kuangye kaifa shi 中国古代矿业开发史 [History of Mining Development in Ancient China]. Beijing: Geological Publishing House.

Xiang, Lifang 项莉芳, and Zheng Jiali 郑嘉励. 2008. “Jingning Bohaikeng: Zhenan Mingdai yinkuang shiyi diaocha zhier” 景宁渤海坑——浙南明代银矿史迹调查之二 [Bohaikeng in Jingning: Investigation of Ming Dynasty Silver Mine Sites in Southern Zhejiang, Part 2]. Dongfang bowu 东方博物 [Cultural Relics of the East], no. 4, 41-45.

Xie, P., and Th. Rehren. 2009. "Scientific Analysis of Lead-Silver Smelting Slag from Two Sites in China." In Metallurgy and Civilisation: Eurasia and Beyond, edited by Th. Rehren and Mei J., 177183. London: Archetype.

Zhao, Guanglin 赵光林. 1984. “Jinjinian Beijing faxian de jichu gudai ciyao zhi” 近几年北京发现 的几处古代瓷窑址 [Several Ancient Porcelain Kiln Sites Discovered in Beijing in Recent Years]. In Zhongguo gudai yaozhi diaocha fajue baogao ji 中国古代窑址调查发掘报告集 [Collection of Reports on the Investigation and Excavation of Ancient Chinese Kiln Sites], edited by Editorial Committee of Cultural Relics, 408-413. Beijing: Cultural Relics Publishing House.

Zheng, Jiali, and Yan Xiaokuan 严晓宽. 2007. “Yunhe Huangjiashe: Zhenan Mingdai yinkuang shiji diaocha zhiyi” 云和黄家畜——浙南明代银矿史迹调查之一 [Huangiiashe Village in Yunhe: Investigation of Ming Dynasty Silver Mine Sites in Southern Zhejiang Province, Part 1]. Dongfang bowu, no. 4, 30-35.

Zhou, Wenli 周文丽, Liu Siran, and Chen Jianli. 2016. “Zhongguo gudai yejin yong ganguo de faxian he yanjiu” 中国古代冶金用坩埚的发现和研究 [Discovery and Study of Metallurgical Crucibles in Ancient China]. Ziran kexueshi yanjiu 35 (3): 358-370.

Zhou, Wenli, Liu Siran, and Chen Jianli. 2017. “Henan Tongbai Weishan yizhi ganguo lianqian jishu chubu yanjiu” 河南桐柏围山遗址坩埚炼铅技术初步研究 [Preliminary Research on the Lead Smelting Technology by Crucible in Weishan Site, Tongbai, Henan Province]. Nanfang wenwu, no. 2, 131-140.

Zhou, Wenli, Liu Siran, Liu Haifeng, and Chen Jianli. 2014. “Zhongguo chuantong ganguo lianqian jishu chutan" 中国传统坩埚炼铅技术初探 [A Preliminary Study of Traditional Chinese Crucible Lead Smelting Technology]. Ziran kexueshi yanjiu 33 (2): 201-215. 